\title{
$\kappa$-Opioid Receptors within the Nucleus Accumbens Shell Mediate Pair Bond Maintenance
}

\author{
Shanna L. Resendez, ${ }^{1}$ Morgan Kuhnmuench, ${ }^{2}$ Tarin Krzywosinski, ${ }^{2}$ and Brandon J. Aragona ${ }^{1,2}$ \\ ${ }^{1}$ Program in Neuroscience and ${ }^{2}$ Department of Psychology, University of Michigan, Ann Arbor, Michigan 48109
}

\begin{abstract}
The prairie vole is a socially monogamous species in which breeder pairs typically show strong and selective pair bonds. The establishment of a pair bond is associated with a behavioral transition from general affiliation to aggressive rejection of novel conspecifics. This "selective aggression" is indicative of mate guarding that is necessary to maintain the initial pair bond. In the laboratory, the neurobiology of this behavior is studied using resident-intruder testing. Although it is well established that social behaviors in other species are mediated by endogenous opioid systems, opiate regulation of pair bond maintenance has never been studied. Here, we used resident-intruder testing to determine whether endogenous opioids within brain motivational circuitry mediate selective aggression in prairie voles. We first show that peripheral blockade of $\kappa$-opioid receptors with the antagonist norbinaltorphimine (nor-BNI; $100 \mathrm{mg} / \mathrm{kg}$ ), but not with the preferential $\mu$-opioid receptor antagonist naloxone $(1,10$, or $30 \mathrm{mg} / \mathrm{kg})$, decreased selective aggression in males. We then provide the first comprehensive characterization of $\kappa$ - and $\mu$-opioid receptors in the prairie vole brain. Finally, we demonstrate that blockade of $\kappa$-opioid receptors ( $500 \mathrm{ng}$ nor-BNI) within the nucleus accumbens (NAc) shell abolishes selective aggression in both sexes, but blockade of these receptors within the NAc core enhances this behavior specifically in females. Blockade of $\kappa$-opioid receptors within the ventral pallidum or $\mu$-opioid receptors with the specific $\mu$-opioid receptor antagonist H-D-Phe-Cys-Tyr-D-Trp-Arg-Thr-PenThr-NH2 (1 ng CTAP) within the NAc shell had no effect in either sex. Thus, $\kappa$-opioid receptors within the NAc shell mediate aversive social motivation that is critical for pair bond maintenance.
\end{abstract}

\section{Introduction}

The socially monogamous prairie vole (Microtus ochrogaster) is an excellent model system to study the neurobiology of social attachment (Young and Wang, 2004; Young et al., 2005; Aragona and Wang, 2009). Prairie voles show species typical pair bonds characterized by sharing territory, nests, and parental responsibilities (Getz et al., 1981, 1993). Initial pair bond formation involves prosocial behaviors that are reliably assayed with the partner preference test (Williams et al., 1992). This behavior is regulated by the processing of social reward within motivational circuitry (Aragona et al., 2003; Liu and Wang, 2003; Lim and Young, 2004; Curtis and Wang, 2005). For example, pair bond formation is facilitated by activation of $\mathrm{D}_{2}$-like dopamine (DA) receptors within the nucleus accumbens (NAc) shell during the initial hours of cohabitation and mating (Aragona et al., 2006). In contrast, the long-term maintenance of the bond requires increases in aversive motivational behavior, such as mate guarding. This is studied in the lab using tests of selective aggression toward

Received Nov. 18, 2011; revised March 26, 2012; accepted March 29, 2012.

Author contributions: B.J.A. designed research; S.L.R., M.K., and T.K. performed research; S.L.R. analyzed data; S.L.R. and B.J.A. wrote the paper.

This work was supported by NSF Grant 0953106 to B.J.A. and a Rackham Merit Fellowship to S.L.R. We acknowledge Zuoxin Wang and Yan Liu (Florida State University) for their assistance with the opiate receptor autoradiography, Jacinta Beehner and Teera Par (Core Assay Facility, University of Michigan) for running the corticosterone assay, Kirsten Alexandra Porter-Stransky for statistical consulting, Dante Bugli for his technical assistance, and Brittany Mash for her illustrations.

The authors declare no competing financial interests.

Correspondence should be addressed to either Dr. Brandon J. Aragona or Shanna L. Resendez, Department of Psychology, University of Michigan, Ann Arbor, MI 48109. E-mail: aragona@umich.edu or slharkey@umich.edu.

DOI:10.1523/JNEUROSC1.5779-11.2012

Copyright $\odot 2012$ the authors $\quad 0270-6474 / 12 / 326771-14 \$ 15.00 / 0$ unfamiliar conspecifics (Gavish et al., 1983; Winslow et al., 1993; Young et al., 1997), and it is known that this behavior is regulated by $\mathrm{D}_{1}$-like receptors within the NAc shell (Aragona et al., 2006). Thus, $\mathrm{D}_{1}$ - and $\mathrm{D}_{2}$-like receptors within the NAc shell—a region important for processing social incentives (Li and Fleming, 2003; Champagne et al., 2004; Trezza et al., 2011)—exert differential regulation over the formation and maintenance of monogamous pair bonds (Aragona et al., 2006).

Differential regulation over pair bonding by $\mathrm{D}_{1}$ - and $\mathrm{D}_{2}$-like receptors is significant because these receptors are primarily expressed on distinct neuron populations (Le Moine and Bloch, 1995; Perreault et al., 2011). $\mathrm{D}_{2}$-like receptors are expressed on neurons that contain enkephalin, an endogenous ligand for $\mu$-opioid receptors that mediate motivation and positive hedonics (Bozarth and Wise, 1981; Gerfen and Young, 1988; Pecina and Berridge, 2005). Conversely, $D_{1}$-expressing neurons contain dynorphin, the endogenous ligand for $\kappa$-opioid receptors that mediates aversion and negative affect (Chavkin et al., 1982; Mucha and Herz, 1985; Pfeiffer et al., 1986). Moreover, activation of $\mathrm{D}_{1}$-like receptors increases dynorphin levels (Gerfen et al., 1990), indicating a direct interaction between these systems. Given this interaction and $\kappa$-opioid regulation over aversion (van Ree et al., 1999; Le Merrer et al., 2009), we hypothesized that $\kappa$-opioid receptors within the NAc shell mediate selective aggression and are therefore important for aversive social motivation.

Here, we conducted a series of experiments to examine opioid regulation of selective aggression in male and female prairie voles. We first tested the effects of global $\kappa$ - and $\mu$-opioid receptor blockade on this behavior and then characterized central opioid receptor distributions in prairie voles. Finally, we tested the in- 
volvement of opioid receptors specifically within the NAc shell, NAc core, or ventral pallidum (VP) on the expression of selective aggression. Our studies demonstrate that $\kappa$-opioid receptors within the NAc shell mediate selective aggression and thus provide the first evidence that this region mediates the aversive social motivational processing critical for pair bond maintenance.

\section{Materials and Methods}

Subjects. Subjects were adult male and female prairie voles (90-150 d old) initially obtained from Florida State University and bred in a laboratory colony at the University of Michigan. Subjects were weaned at $21 \mathrm{~d}$ of age and housed with same-sex cage mates (two per cage, typically siblings) in a $14 \mathrm{~h} \mathrm{light/10} \mathrm{h} \mathrm{dark} \mathrm{cycle} \mathrm{(lights} \mathrm{on} \mathrm{at} \mathrm{6:00} \mathrm{A.M.} \mathrm{and} \mathrm{off} \mathrm{at} \mathrm{8:00} \mathrm{P.M.),}$ and all experiments were conducted in the light phase of the animals. Food and water were available ad libitum. All procedures were conducted in accordance with the animal care guidelines of the University of Michigan.

Cohabitation, mating, and pregnancy. Adult males and intact, nonestrogen primed females were paired for a 2 week cohabitation period (Aragona et al., 2006; Gobrogge et al., 2009). This length of cohabitation, as well as the occurrence of mating during this period, has been used to infer pair bonding as characterized by selective affiliation toward the familiar partner and selective aggression toward novel conspecifics (Aragona et al., 2006; Gobrogge et al., 2009). However, recent data show that mating alone is not sufficient for reliable pair bonding (Curtis, 2010). This study demonstrates that for a pair bond to be consistently established, the pair must achieve estrous, mating, ovulation, and impregnation within an optimal time frame (Curtis, 2010). For this reason, the present study characterized the relationships between mating onset and pregnancy as well as the relationship between pregnancy status of the female and selective aggression (i.e., the behavioral index of pair bond maintenance) (Carter and Getz, 1993; Aragona and Wang, 2009).

Social interactions were recorded for the first $72 \mathrm{~h}$ of the cohabitation period, and the latency to initiate mating as well as the number of mating bouts were quantified for this entire period. Once behavioral testing was completed, we determined whether females were pregnant and estimated the duration of the pregnancy by measuring neonatal weight. While mating onset and neonatal weight were positively correlated $\left(r_{(52)}=-0.40\right.$, $p=0.0024$; data not shown), there were instances wherein mating occurred but no pregnancy resulted. Importantly, males in these pairs were less likely to show selective aggression (below). It was therefore determined that rapid and successful establishment of pregnancy as measured by neonatal weight is a better method to assess whether a cohabitation is likely to be associated with pair bonding rather than relying on the onset of mating behavior during the cohabitation. Thus, the current and previous studies (Curtis, 2010) indicate that future studies of pair bonding should quantify pregnancy, rather than simply determining copulatory behavior during the cohabitation period, when attempting to approximate the likelihood of a pair bond.

To directly determine the relationship between pregnancy and selective aggression, the stage of pregnancy was estimated based on neonatal weight and characterized as optimally pregnant (pregnancy achieved shortly following the onset of cohabitation) or suboptimally pregnant (delayed pregnancy onset) (Curtis, 2010). Previous studies have used neonatal length to categorize the stage of pregnancy in prairie voles (Curtis, 2010); therefore, in a subgroup of animals, we also measured the length of the fetus at the time of testing and plotted these values against the weight of the fetus. We found that weights $>0.3 \mathrm{~g}$ corresponded to lengths of $10 \mathrm{~mm}(>10 \mathrm{~d}$ pregnant) and therefore were indicative of optimal impregnation, while $\sim 0.165$ g corresponded to lengths of $5 \mathrm{~mm}$ (3-5 d pregnant) and were thus indicative of suboptimal pregnancy (Curtis, 2010). Subjects were then categorized as either optimally (neonatal weight $>0.3 \mathrm{~g}$ ) or suboptimally (neonatal weight of $0-0.3 \mathrm{~g}$ ) pregnant, and mean selective aggression frequencies between these groups were compared with a $t$ test.

Resident-intruder test. Resident-intruder testing was conducted between 14 and $17 \mathrm{~d}$ into the cohabitation. Both members of the breeder pair were tested, males and females were tested in counterbalanced fash- ion, and there was no order effect. Before the resident-intruder test, the first test subject of the pair received either a peripheral or site-directed injection of an opiate receptor antagonist (see Peripheral drug administration, below) and was returned to the home cage with its partner. The second test subject received an injection $30 \mathrm{~min}$ following the first subject so that behavioral tests occurred within $30 \mathrm{~min}$ of each other. The resident-intruder test occurred $1 \mathrm{~h}$ following drug administration and began with a $10 \mathrm{~min}$ habituation period in the testing room. Before the $10 \mathrm{~min}$ habituation period, the member of the breeder pair that was not being tested first was removed from the home cage and placed in a novel cage for no more than $30 \mathrm{~min}$. During the habituation period, locomotor activity was recorded, and the number of cage crossings during the last $10 \mathrm{~min}$ of this period was scored by an experimentally blind observer using Behavior Tracker 1.0 software to determine whether opiate receptor antagonists altered general locomotor activity.

Following the habituation period, the resident-intruder test was initiated by placing a same-sex intruder into the test subject's home cage, and behavioral interactions were recorded for $10 \mathrm{~min}$ (Gobrogge et al., 2009). Same-sex intruders were chosen because previous research has shown that pair-bonded animals show consistently high levels of aggression toward same-sex intruders, whereas this behavior is more modest and variable with opposite-sex intruders (Firestone et al., 1991a; Wang et al., 1997; Aragona et al., 2006). The frequency of aggressive interactions (lunges, bites, chases, offensive rears) and duration of affiliative behaviors (olfactory investigation, anogenital sniff, side-by-side contact) were quantified using Behavior Tracker 1.0 software by an experimentally blind observer. Immediately following the test, stimulus animals were removed, and subjects were killed via rapid decapitation, and trunk blood was collected; for animals in the site-specific study, brains were rapidly removed and frozen.

Peripheral drug administration. To determine whether global blockade of $\kappa$ - or $\mu$-opioid receptors alter selective aggression, either the $\kappa$-opioid receptor antagonist [norbinaltorphimine (nor-BNI] (Portoghese et al., 1987 ) or the preferential $\mu$-opioid receptor antagonist (naloxone) (Magnan et al., 1982) was administered intraperitoneally $1 \mathrm{~h}$ before the resident-intruder test. To control for vehicle injection, a $0.2 \mathrm{ml}$ injection of sterile saline was given ( $n=9$ male; $n=11$ female). All drugs were dissolved in sterile saline and mixed up fresh on the day of use. In addition to saline controls, we ran a separate group of handled, but not injected, controls ( $n=9$ male; $n=9$ female) and found no behavioral difference between saline or noninjected controls (male, $t_{(16)}=0.92, p=0.37$; female, $t_{(18)}=0.63, p=0.57$; control groups were therefore combined for statistical analysis).

The doses of nor-BNI tested were as follows: $10 \mathrm{mg} / \mathrm{kg}(n=10 \mathrm{male}$; $n=10$ female), $32 \mathrm{mg} / \mathrm{kg}(n=10$ male; $n=11 \mathrm{female}), 50 \mathrm{mg} / \mathrm{kg}(n=$ 10 male; $n=9$ female), or $100 \mathrm{mg} / \mathrm{kg}(n=7$ male; $n=10$ female $)$ (Broadbear et al., 1994). While the higher doses used in this study (50 and $100 \mathrm{mg} / \mathrm{kg}$ ) are higher than those used in rats and mice, prairie voles remain ambulatory and show species typical social interactions at these doses. Additionally, to validate the use of high doses of nor-BNI for behavioral studies in prairie voles, we conducted additional behavioral tests using behavioral assays for which the effects of opioid drugs in other species have been well established (tests for locomotor activity and analgesia; described below).

The doses of naloxone used were as follows: $1 \mathrm{mg} / \mathrm{kg}(n=11 \mathrm{male} ; n=$ $12 \mathrm{female}), 10 \mathrm{mg} / \mathrm{kg}(n=10 \mathrm{male} ; n=10 \mathrm{female})$, or $30 \mathrm{mg} / \mathrm{kg}(n=11$ male; $n=12$ female). These doses were chosen because $1 \mathrm{mg} / \mathrm{kg}$ (but not lower doses) of naloxone has been shown to decrease aggression in mice (Haug et al., 1986). While this dose $(1 \mathrm{mg} / \mathrm{kg}$ ) has also been shown to decrease locomotor behavior in rats (Sisti and Lewis, 2001), it had no effect on either locomotor activity or selective aggression in prairie voles (see below). We therefore used two higher doses, $10 \mathrm{mg} / \mathrm{kg}$ (Grimm et al., 2007) and $30 \mathrm{mg} / \mathrm{kg}$, and these doses ensured that the lack of effect on selective aggression by naloxone treatment was not due to using a behaviorally ineffective dose because these higher doses significantly decreased general locomotor activity in females (Table 1).

Stereotaxic cannulation and microinfusion. Following $14 \mathrm{~d}$ of cohabitation, both males and females received stereotaxic surgery and then recovered together for $3 \mathrm{~d}$ in their home cage. Consistent with the methods 
Table 1. Number of cage crosses in home cage $1 \mathrm{~h}$ following peripheral injections of nor-BNI

\begin{tabular}{lll}
\hline & Male & Female \\
\hline nor-BNI & & \\
$\quad$ Control & $23.9 \pm 7.4$ & $30.7 \pm 4.1$ \\
$10 \mathrm{mg} / \mathrm{kg}$ & $34.0 \pm 12.9$ & $39.8 \pm 6.2$ \\
$32 \mathrm{mg} / \mathrm{kg}$ & $28.6 \pm 7.2$ & $18.2 \pm 5.3$ \\
$50 \mathrm{mg} / \mathrm{kg}$ & $24.1 \pm 5.0$ & $24.6 \pm 5.8$ \\
$100 \mathrm{mg} / \mathrm{kg}$ & $12.9 \pm 8.8$ & $26.5 \pm 11.6$ \\
Naloxone & & \\
$\quad$ Control & $23.9 \pm 7.4$ & $30.7 \pm 4.6$ \\
$1 \mathrm{mg} / \mathrm{kg}$ & $21.1 \pm 5.2$ & $28.5 \pm 6.9$ \\
$10 \mathrm{mg} / \mathrm{kg}$ & $27.3 \pm 12.1$ & $16.0 \pm 4.3^{*}$ \\
$30 \mathrm{mg} / \mathrm{kg}$ & $24.7 \pm 4.6$ & $13.9 \pm 2.1^{*}$ \\
\hline
\end{tabular}

During the habituation period, peripheral administration of nor-BNI had no effect on the locomotor activity of male or female prairie voles at any dose tested. Peripheral administration of naloxone had no effect on the locomotor activity of males, but caused a significant decrease in female locomotor activity at the two highest doses. ${ }^{*} p<0.05$.

established by previous studies (Liu and Wang, 2003; Aragona et al., 2006), subjects were implanted with 26-guage bilateral guide cannulae (Plastics One) anchored to the skull with stainless-steel screws and dental cement and aimed at the NAc shell $(+1.6 \mathrm{~mm} \mathrm{AP} ; \pm 1 \mathrm{~mm} \mathrm{ML} ;-4.5 \mathrm{~mm}$ $\mathrm{DV})$, NAc core ( $+1.6 \mathrm{~mm} \mathrm{AP} ; \pm 1 \mathrm{~mm} \mathrm{ML} ;-3.5 \mathrm{~mm} \mathrm{DV})$, or the VP $(+0.45 \mathrm{~mm} \mathrm{AP} ; \pm 1 \mathrm{~mm} \mathrm{ML} ;-4.5 \mathrm{~mm} \mathrm{DV})$. Injection sites for both the NAc and the VP corresponded to regions in which autoradiography determined that $\kappa$-opioid receptor binding was dense (see Figs. 5, 6).

On the test day, a 33-guage injector was used to infuse either artificial CSF (ACSF; male, $n=8$, NAc shell; $n=6$, NAc core; female, $n=6$, NAc core; $n=7$, NAc shell), ACSF containing 500 ng of nor-BNI (male, $n=$ 7, NAc core; $n=8$, NAc shell; $n=8$, NAc VP; female, $n=7$, shell; $n=6$, core; $n=6, \mathrm{VP}$ ), or ACSF containing $1 \mathrm{ng}$ of the highly selective $\mu$-opioid receptor antagonist H-D-Phe-Cys-Tyr-D-Trp-Arg-Thr-Pen-Thr-NH2 CTAP (Pelton et al., 1986) into the NAc shell (male, $n=5$; female, $n=5$ ) (Simmons and Self, 2009). Following behavioral testing, stimulus animals were removed, subjects were killed via rapid decapitation, trunk blood was obtained, and brains were extracted and frozen for subsequent histological verification of cannulae placements. Only subjects whose cannulae placements were in the target region were included in the study.

Receptor autoradiography. At $90 \mathrm{~d}$ of age, sexually naive male and female prairie voles were killed via rapid decapitation. Brains were rapidly removed, frozen on dry ice, and stored at $-80^{\circ} \mathrm{C}$. Brains were sectioned on a cryostat at $15 \mu \mathrm{m}$ in four serial sections (i.e., $60 \mu \mathrm{m}$ intervals) and placed back in the $-80^{\circ} \mathrm{C}$ freezer until all samples were ready to be processed. On the day of processing, slides were washed twice in room temperature $50 \mathrm{~mm}$ Tris- $\mathrm{HCl}, \mathrm{pH} 7.4$ for $10 \mathrm{~min}$. Samples were then incubated in either $\mu$-opioid receptor ligand (DAMGO; PerkinElmer, catalog \#NET 902; lot \#3615807) for $1 \mathrm{~h}$ or with the $\kappa$-opioid receptor ligand $\left(\mathrm{C}_{22} \mathrm{H}_{3} 2 \mathrm{~N}_{2} \mathrm{O}_{2}\right.$; U69,593; PerkinElmer; catalog \#NET 952; lot $\# 3615650$ ) for $2 \mathrm{~h}$. The incubation period was followed by a series of washes that are listed as follows: ice-cold Tris buffer (two times for $5 \mathrm{~min}$ each), chilled Tris-buffer while stirring (two times for $10 \mathrm{~min}$ each), dipping in ice-cold distilled water (three times), and then drying under a cool stream of air. Nonspecific binding was determined by incubating a subset of slides with $1 \mu \mathrm{M}$ naloxone for $\mu$ receptors or $1 \mu \mathrm{M}$ nor-BNI for $\kappa$ receptors. Kodak BioMax MS film was then laid on the slides and exposed for 6 months. Film images were captured using a Scan Maker 1000XL Microtek scanner.

Cortisol assay. Previous studies have demonstrated that although norBNI blocks the negative behavioral and physiological consequences of stress, it does not itself decrease corticosterone levels (McLaughlin et al., 2006b). Given that this was the first study using nor-BNI in prairie voles and the aversive nature of selective aggression, we determined the relationship between the actions of nor-BNI on corticosterone in prairie voles as there is in mice. Following rapid decapitation, trunk blood was collected from each subject in tubes containing heparin-coated rings and placed on ice until all behavioral tests for that day were complete (maximum of $4 \mathrm{~h}$ ). Samples were centrifuged at $2000 \times \mathrm{g}$ for $20 \mathrm{~min}$ at $4^{\circ} \mathrm{C}$, and plasma was immediately frozen. Plasma ( $5 \mu$ plasma/10 $\mathrm{ml}$ buffer) was later assayed for corticosterone using a radioimmunoassay [MP Biomedicals corticosterone (rat); catalog \#07-120103]. Given that this is the first time the MP Biomedicals corticosterone antibody has been used for prairie voles, it was analytically validated for use on this species. The slope of the line for serial dilutions of vole serum (plotted as dose per unit volume) was both linear $\left(R^{2}=0.994, p<0.0001\right)$ and parallel to the standard curve. Mean accuracy (determined by spiking kit standards with a high and low vole serum samples) was $95.9 \%$ for the high sample $(N=6)$ and $94.0 \%$ for the low sample $(N=6)$. The intra-assay coefficient of variation $(\mathrm{CV}$; determined by running six duplicates in the same assay) for a high kit control was 3.1\% $(N=6)$, and a low kit control it was $5.1 \%(N=6)$. The interassay CVs for high and low kit controls were $5.7 \%$ $(N=4)$ and $6.3 \%(N=4)$, respectively.

Testosterone assay. In other species, testosterone is known to regulate aggressive behavior (Edwards, 1968; Bronson and Desjardins, 1969; Schuurman, 1980). To determine whether testosterone is important for the display of selective aggression in pair-bonded prairie voles, plasma samples were collected from control subjects (male, $n=$ 14; female, $n=18$ ) and processed as described above and assayed for testosterone (Calbiotech 96-well Testosterone ELISA Kit (mouse/ rat); catalog \#TE187S-100).

Validation of $\kappa$-opioid receptor drug dosing. As our initial behavioral pharmacology testing indicated that prairie voles require high doses of $\kappa$-opioid receptor drugs, we determined the behaviorally effective dose of nor-BNI necessary to block well established motor inhibitory and analgesic effects of a selective $\kappa$-opioid receptor agonist in prairie voles. The use of these validated behavioral assays in prairie voles allowed us to compare the response to $\kappa$-opioid receptor drugs in prairie voles to those of other species with established dose-response curves.

The selective $\kappa$-opioid receptor agonist $\mathrm{C}_{19} \mathrm{H}_{26} \mathrm{Cl}_{2} \mathrm{~N}_{2} \mathrm{O} \times \mathrm{HCl} \times \mathrm{H}_{2} \mathrm{O}$ U50,488 (Von Voigtlander and Lewis, 1982) was dissolved in sterile saline and administered by intraperitoneal injection at a dose of $0 \mathrm{mg} / \mathrm{kg}$ (male, $n=7$; female, $n=7$ ), $5 \mathrm{mg} / \mathrm{kg}$ (male, $n=7$; female, $n=7$ ), 10 $\mathrm{mg} / \mathrm{kg}$ (male, $n=8$; female, $n=6$ ), or $25 \mathrm{mg} / \mathrm{kg}$ (male, $n=5$ ). The 25 $\mathrm{mg} / \mathrm{kg}$ dose was not tested in females because a significant effect was achieved following a $10 \mathrm{mg} / \mathrm{kg}$ administration of U50,488. The doses of U50,488 used in the present study were chosen because they have been demonstrated previously to decrease motor activity (Ukai and Kameyama, 1985; Schnur and Walker, 1990; Leyton and Stewart, 1992; Brent, 1993; Kuzmin et al., 2000; Mague et al., 2003) and enhance analgesia (Kuzmin et al., 2000; McLaughlin et al., 2006b) in other species.

Following identification of the dose of U50,488 that significantly decreased locomotor activity ( $25 \mathrm{mg} / \mathrm{kg}$ for males and $10 \mathrm{mg} / \mathrm{g}$ for females), subjects were administered intraperitoneal injections of nor-BNI $1 \mathrm{~h}$ before U50,488 at a dose of $0 \mathrm{mg} / \mathrm{kg}$ (male, $n=6$; female, $n=6$ ), 10 $\mathrm{mg} / \mathrm{kg}$ (male, $n=6$; female, $n=6$ ), $50 \mathrm{mg} / \mathrm{kg}$ (male, $n=9$; female, $n=$ 6), or $100 \mathrm{mg} / \mathrm{kg}$ (male, $n=7$; female, $n=6$ ). Control subjects received saline injections $1 \mathrm{~h}$ before and immediately before testing (male, $n=11$; female, $n=6$ ). Locomotor activity was assessed with an open-field test, and analgesia was measured with a tail flick assay.

Open-field and tail flick: for open-field testing, subjects were placed in a $75 \times 25 \mathrm{~cm}$ open-field chamber for $1 \mathrm{~h}$ immediately following drug administration (Kuzmin et al., 2000; Mague et al., 2003). Behavior during the open-field test was recorded and later scored for the duration of time spent in forward locomotion and wall climbing. The total duration spent in forward locomotion and wall climbing were combined for a measure of total activity. For tail flick, antinociceptive measurements were made $1 \mathrm{~h}$ following administration of U50,488 by immersing the tail in $55^{\circ} \mathrm{C}$ water for a maximum of $15 \mathrm{~s}$ (McLaughlin et al., 2006a,b). Because baseline analgesia measures of male and female prairie voles were higher than those reported for other species (Butelman et al., 1993; McLaughlin et al., 2006b), C57BL/6 mice were also tested under control conditions (i.e., $1 \mathrm{~h}$ following an intraperitoneal injection of saline). Adult male $(n=5)$ and female $(n=7)$ C57BL/6 mice were housed in a $12 \mathrm{~h}$ reversed light/dark cycle with ad libitum food and water. For detailed analysis, see Tables 2 and 3 as well as Figure 3. Briefly, these experiments 
Table 2. Mean latency to withdraw tail following peripheral injections of $U 50,488$

\begin{tabular}{lllll}
\hline & Saline & $5 \mathrm{mg} / \mathrm{kg}$ & $10 \mathrm{mg} / \mathrm{kg}$ & $25 \mathrm{mg} / \mathrm{kg}$ \\
\hline Male prairie vole & $4.1 \pm 0.7$ & $3.4 \pm 0.6$ & $10.9 \pm 1.4^{* *}$ & $8.6 \pm 2.6$ \\
Female prairie vole & $9.3 \pm 2.1$ & $5.3 \pm 1.7$ & $10.5 \pm 2.0$ & \\
Male C57BL6 mouse & $2.2 \pm 0.1$ & & & \\
Female C57BL6 mouse & $2.1 \pm 0.2$ & & & \\
\hline
\end{tabular}

Peripheral administration of $10 \mathrm{mg} / \mathrm{kg}$ of the $\kappa$-opioid receptor agonist U50,488 significantly increased mean tail withdraw latency in male prairie voles, but did not have a significant effect at the higher dose tested. In females, U50,488 did not increase tail withdraw latency at any of the doses tested. However, females had significantly higher baseline analgesia levels compared to male prairie voles and female C57BL6 mice.

${ }^{* *} p<0.005$.

Table 3. Mean latency to withdraw tail following pretreatment with nor-BNI and peripheral injections of U50,488 (male, $25 \mathrm{mg} / \mathrm{kg}$; female, $10 \mathrm{mg} / \mathrm{kg}$ )

\begin{tabular}{|c|c|c|c|c|c|}
\hline & \multirow[b]{2}{*}{ Saline/saline } & \multicolumn{4}{|l|}{ nor-BNI } \\
\hline & & $0 \mathrm{mg} / \mathrm{kg}$ & $10 \mathrm{mg} / \mathrm{kg}$ & $50 \mathrm{mg} / \mathrm{kg}$ & $100 \mathrm{mg} / \mathrm{kg}$ \\
\hline Male prairie vole & $6.3 \pm 1.2$ & $9.0 \pm 1.9$ & $10.7 \pm 1.5$ & $7.7 \pm 1.9$ & $5.3 \pm 1.7$ \\
\hline Female prairie vole & $10.9 \pm 1.9$ & $7.8 \pm 1.5$ & $5.8 \pm 0.7$ & $4.7 \pm 2.1$ & $6.0 \pm 1.4$ \\
\hline
\end{tabular}

There were no significant differences on tail withdrawal latency between control male or female subjects (saline/ saline) and those pretreated with various doses of nor-BNl as well as the highest dose of the $\kappa$-opioid receptor agonist U50,488 administered to each sex (male, $25 \mathrm{mg} / \mathrm{kg}$; female, $10 \mathrm{mg} / \mathrm{kg}$ ).

confirm that high doses of $\kappa$-opioid receptor drugs are needed for behavioral manipulations using prairie voles.

Statistics. A linear regression analysis was computed to determine the relationship between neonatal weight and mating and to determine whether neonatal weight was associated with levels of selective aggression. A linear regression analysis was also used to determine the relationship between neonatal weight and mating onset as well as the relationship between hormone (corticosterone and testosterone) levels and aggression and pregnancy stage. Since previous studies have demonstrated that male prairie voles are generally more aggressive than females (Winslow et al., 1993), we used a $t$ test to compare attack frequencies and affiliation levels during resident-intruder testing between control males and females. Regarding pharmacological manipulations of selective aggression, it was hypothesized that blockade of $\kappa$-but not $\mu$-opioid receptors would interfere with selective aggression. Therefore, a one-way ANOVA followed by a Tukey's post hoc test was used to assess the pharmacological effects of peripheral opioid receptor blockade on selective aggression. Additionally, since multiple doses were used, a series of planned contrast was used to determine whether peripheral opioid receptor blockade decreased aggression in a dose-dependent manner (Zhang and Kelley, 1997). For site-specific comparisons, it was hypothesized that blockade of $\kappa$-opioid receptors within the NAc shell, but not other regions, would significantly decrease aggression compared to saline controls. Given the Levene test of homogeneity of variances failed for site-specific data, a one-way ANOVA could not be used, and thus a Mann-Whitney $U$ test (Stribley and Carter, 1999) was conducted to test whether site-directed blockade of opioid receptors decreased aggression levels compared to controls. Plasma corticosterone levels following nor-BNI treatments were compared to controls using a one-way ANOVA followed by a Tukey's post hoc test. A one-way ANOVA followed by a Tukey's post hoc test was also used to determine the effects of a $\kappa$-opioid receptor agonist or antagonist on locomotor activity and analgesia. A $t$ test was used to compare sex and species differences in baseline analgesia. All analysis was performed with the use of SPSS Statistics 17.0 software.

\section{Results}

\section{Fecundity and pair bonding}

While prairie voles are socially monogamous, males of this species display important individual variation in reproductive strategy (Getz et al., 1993; Solomon et al., 2009). In natural prairie vole populations, approximately one-half of males "wander" across multiple female territories attempting to mate with multiple females (Getz et al., 1993; Solomon and Jacquot, 2002), and the biological basis of this variation continues to be studied (Fink et
A

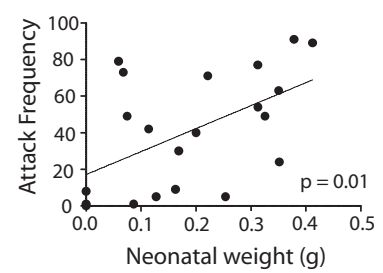

C
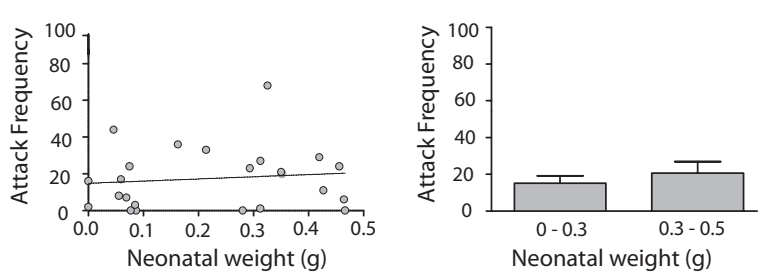

Figure 1. Selective aggression in males is associated with the pregnancy status of the female. $\boldsymbol{A}, \boldsymbol{B}$, Aggression in males is related to neonatal weight at the time of testing ( $n=21 ; \boldsymbol{A})$, and males whose females are farther along in gestation are more aggressive than males ( $n=$ 14 ) whose females have more recently become pregnant $(n=7 ; \boldsymbol{B}) . \boldsymbol{C}, \boldsymbol{D}$, Conversely, aggression levels in females has no relation to pregnancy status ( $n=24 ; C$ ) as females who are farther along in pregnancy $(n=14)$ do not become more aggressive than females who have more recently become pregnant $(n=7 ; \boldsymbol{D}) .{ }^{*} p<0.05$. Error bars indicate mean \pm SEM.

al., 2006; Young and Hammock, 2007; Ophir et al., 2008; Mabry et al., 2011). It was shown previously that environmental factors also contribute to mating strategy in this species as male prairie voles do not show partner preferences after long-term cohabitation unless pregnancy is established soon after pairing (Curtis, 2010). However, the relationship between fertility and selective aggression has never been formally assessed. In previous studies of selective aggression, pairs that failed to achieve pregnancy following a 2 week cohabitation were simply excluded from the studies (Aragona et al., 2006; Gobrogge et al., 2009). Here, we provide the first examination of the relationship between pregnancy and selective aggression by comparing neonatal weight at the time of testing to attack frequency in both male and female subjects.

In males, neonatal weight was positively correlated with attack frequency $\left(R^{2}=0.28, F_{(1,19)}=7.55, p=0.01\right)$ (Fig. $\left.1 A\right)$. Consistent with a previous study (Curtis, 2010), pregnancy was considered optimal if offspring size indicated that the pair achieved behavioral estrous, ovulation, and fertilization with minimal delay following the onset of the cohabitation. This corresponded to an average neonatal weight of $>0.30 \mathrm{~g}$ at the time of residentintruder testing. Males whose females were in an optimal stage of pregnancy were significantly more aggressive than males whose females were suboptimally pregnant $\left(t_{(19)}=2.67, p=0.02\right.$ ) (Fig. $1 B)$. However, there was no difference in selective aggression in female subjects depending on optimal versus suboptimal pregnancy $\left(t_{(22)}=0.78, p=0.44\right)($ Fig. $1 D)$. There was also no correlation between neonatal weight and aggression in females $\left(R^{2}=0.01, F_{(1,22)}=0.29, p=0.59\right)$ (Fig. 1C). This is similar to previous laboratory studies showing that long-term cohabitation, but not mating, was correlated with aggression in females (Bowler et al., 2002) as well as data from the field that show no correlation between stage of pregnancy and wounding (a proxy for aggressive encounters) (Rose and Gaines, 1976). These data suggest that it is adaptive for males, but not females, to form pair bonds depending on reproductive success. This is reasonable if indeed the function of selective aggression is primarily mate 
guarding to increase assurance of paternity. Conversely, the decision for females to bond may be based heavily on the degree of male investment, which is held constant under the preset experimental conditions (a continual presence for 2 weeks). Thus, more naturalistic circumstances may be needed to examine variation in selective aggression shown by females.

As we describe below, an important component of this study was to determine whether opioid receptor manipulations altered corticosterone levels. Additionally, the presence of acute aversive stimuli, including those of a social nature, increase plasma corticosterone levels (Schuurman, 1980; Buwalda et al., 2011). The resident-intruder paradigm can also be aversive in nature, and this also provided a need for the relationship between selective aggression and corticosterone levels to be determined in the present study. In males, attack frequency was positively correlated with plasma corticosterone levels $\left(R^{2}=0.33, F_{(1,17)}=8.23, p=\right.$ $0.01)$. However, there was no relationship between attack frequency and plasma corticosterone levels in females $\left(R^{2}=0.005\right.$, $F_{(1,21)}=0.12, p=0.74$; data not shown).

Additionally, because testosterone has been implicated in general aggression in other species (Beeman, 1947; Edwards, 1968; Bronson and Desjardins, 1969; Schuurman, 1980), the relationship between selective aggression and plasma testosterone was also assessed. There was no relationship between plasma testosterone and attack frequency in males $\left(R^{2}=0.004, F_{(1,13)}=0.06\right.$, $p=0.82)$ and females $\left(R^{2}=0.16, F_{(1,17)}=3.15, p=0.09\right.$; data not shown). This is consistent with previous reports that have indicated that testosterone does not mediate selective aggression in pair bonded prairie vole (Carter and Getz, 1993). These data support the contention that this behavior is not representative of generalized aggression. Rather, selective aggression is indicative of the behavioral transformation that is associated with the development of a pair bond.

\section{Effect of peripheral blockade of opioid receptor on selective aggression}

Although there are quantitative differences in selective aggression between male and female prairie voles, both sexes show this behavior (Getz et al., 1981). Initially, sexually naive prairie voles are quite affiliative toward novel conspecifics (Aragona et al., 2006). However, once pair bonded, such affiliation is directed more selectively toward familiar conspecifics, especially the breeding partner. Thus, there is a behavioral transition in selective affiliation and aggression, with non-pair-bonded voles being generally affiliative and then becoming more aggressive once pair bonded (Getz, 1978; Carter and Getz, 1993; Young et al., 1998; Aragona et al., 2006; Aragona and Wang, 2009). In the laboratory, residentintruder testing using unfamiliar same-sex stimulus animals is used to quantify selective aggression in both male and female prairie voles (Carter et al., 1997) and provides a quantification of mate guarding and thus pair bond maintenance. Consistent with previous studies that have shown that males are more aggressive than females (Gavish et al., 1981; Firestone et al., 1991b; Carter et al., 1997), we found a significant sex difference in the magnitude of selective aggression with control males showing significantly greater attack frequency compared to control female subjects (Fig. $2 C, D)\left(t_{(58)}=2.97, p=0.004\right)$. However, there was no sex difference in affiliative behavior toward resident-intruders (Figs. $2 A, B)\left(t_{(58)}=0.54, p=0.59\right)$.

Given that selective aggression is a form of aversive motivation and that $\kappa$-opioid receptors mediate aversion (van Ree et al., 1999; Le Merrer et al., 2009), we hypothesized that these receptors would be important for selective aggression, whereas $\mu$-opioid
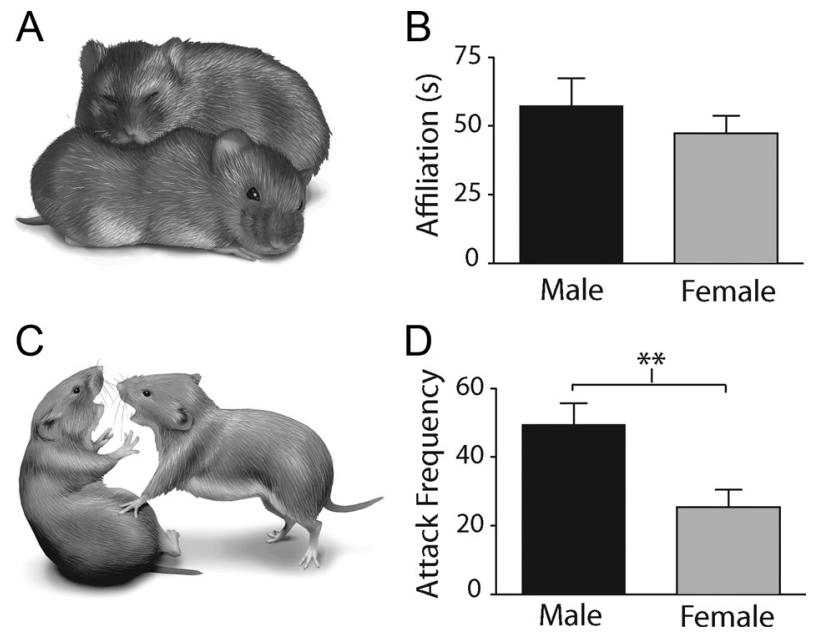

Figure 2. Selective affiliation and selective aggression in male and female prairie voles. $\boldsymbol{A}$ Diagram of prairie vole engaging in one type of affiliative behavior measured in the present study, side by side contact. $\boldsymbol{B}$, Pair-bonded male $(n=18)$ and female $(n=21)$ prairie voles do not differ in the amount of social affiliation with novel individuals. $C$, Pair-bonded prairie vole (right) lunging at a resident intruder (left) who responds by displaying a characteristic submissive posture. $\boldsymbol{D}$, Following pair bond formation, both sexes of the breeding pair show selective aggression to novel conspecifics. However, males of the breeding pair become significantly more aggressive than females. ${ }^{* *} p<0.005$. Error bars indicate mean \pm SEM.

receptors (i.e., receptors that mediate reward) would not be involved in this behavior. Consistent with this hypothesis, peripheral injections of the $\kappa$-opioid receptor antagonist nor-BNI dosedependently reduced the frequency of attacks in male prairie voles $\left(F_{(4,50)}=3.22, p=0.02\right)$ (Fig. $\left.3 A\right)$. Post hoc tests revealed that animals receiving the highest dose of nor-BNI showed significantly lower levels of selective aggression $(p=0.02)$, and planned contrast comparisons indicated that nor-BNI decreased aggression in a linear manner $\left(t_{(50)}=-3.40, p=0.001\right)$ (Fig. $3 A)$. Groups did not differ in attack latency $\left(F_{(4,50)}=2.29, p=\right.$ 0.07 ) (Fig. 3B), affiliation $\left(F_{(4,50)}=1.30, p=0.28\right)$ (Fig. 3D), or general locomotor activity $\left(F_{(4,50)}=0.69, p=0.08\right)$ (Table 1$)$. In contrast to $\kappa$-opioid receptor blockade, blockade of $\mu$-opioid receptors in males with the preferential $\mu$-opioid receptor antagonist naloxone had no effect on attack frequency $\left(F_{(3,46)}=0.71\right.$, $p=0.55$ ) (Fig. $4 A$ ), attack latency $\left(F_{(3,46)}=2.3, p=0.90\right)$ (Fig. $4 B$ ), affiliative behavior $\left(F_{(3,46)}=0.33, p=0.80\right)$ (Fig. $\left.4 C\right)$, or locomotor behavior $\left(F_{(3,46)}=0.21, p=0.89\right)$ (Table 1$)$.

In females, peripheral administration of nor-BNI did not significantly alter attack frequency $\left(F_{(4,54)}=1.65, p=0.19\right.$ ) (Fig. $3 F)$. However, nor-BNI caused a significant increase in latency to $\operatorname{attack}\left(F_{(4,54)}=2.89, p=0.03\right)$ (Fig. $\left.3 G\right)$, although post hoc tests did not identify a specific dose that was most effective. There was no effect on affiliative behavior $\left(F_{(4,54)}=0.60, p=0.67\right)$ (Fig. 3I) or locomotor activity $\left(F_{(4,54)}=2.07, p=0.10\right)$ (Table 1$)$. Naloxone had no effect on selective aggression in females $\left(F_{(3,50)}=\right.$ $1.03, p=0.40)($ Fig. $4 D)$, and this was despite that the higher dose of naloxone caused a significant decrease in locomotor activity in females $\left(F_{(3,50)}=4.75, p=0.005\right)$ (Table 1$)$.

The behaviorally effective dose of nor-BNI (100 mg/kg; i.e., the dose that decreased selective aggression) was 10-fold higher than doses reported to be effective in other rodent species (mice and rats) (Lindholm et al., 2001; McLaughlin et al., 2003; McCurdy et al., 2006; Zhang et al., 2007). To validate the need for higher doses in prairie voles, we determined the dose of nor-BNI that reversed the inhibitory motor effects of the $\kappa$-opioid receptor agonist U50,488 in an open-field apparatus. 
In males, the highest dose of U50,488 $(25 \mathrm{mg} / \mathrm{kg})$ significantly decreased total activity in the open-field test $\left(F_{(3,26)}=\right.$ 5.69, $p=0.009$ ) (Fig. $3 C$ ), and this was reversed by $50 \mathrm{mg} / \mathrm{kg}\left(F_{(4,38)}=9.335, p=\right.$ 0.328 ) and $100 \mathrm{mg} / \mathrm{kg}$ nor-BNI $(p=$ $0.246)$, but not $10 \mathrm{mg} / \mathrm{kg}$ nor-BNI $(p<$ 0.0001 ) (Fig. 3E). Thus, higher doses of nor-BNI are needed to alter motor activity compared to other rodent species (Lindholm et al., 2001; McLaughlin et al., 2003; McCurdy et al., 2006; Zhang et al., 2007). Behavioral assays of analgesia also demonstrated species differences in $\kappa$-opioid receptor pharmacology. Voles have higher baseline analgesia compared to mice (Table 2 ), and higher doses of the $\kappa$-opioid receptor agonist were needed to enhance antinociception (Tables 2, 3) (McLaughlin et al., 2006b).

In females, a lower dose of U50,488 was needed to decrease locomotor activity than was necessary compared to how this drug impacted male prairie voles. Specifically, $10 \mathrm{mg} / \mathrm{kg}$ U50,488 significantly decreased total activity $\left(F_{(2,19)}=7.05, p=\right.$ 0.02) (Fig. $3 H$ ), and this decrease was reversed by $50 \mathrm{mg} / \mathrm{kg}\left(F_{(4,29)}=10.14, p=\right.$ $0.46)$ and $100 \mathrm{mg} / \mathrm{kg}$ nor-BNI $(p=0.76)$, but not $10 \mathrm{mg} / \mathrm{kg}(p<0.0001)$ (Fig. 3J). With respect to the tail withdrawal assay, female prairie voles showed a significantly higher baseline level of analgesia compared to male prairie voles $\left(t_{(12)}=2.322, p=0.0386\right.$ ) (Table 2$)$ as well as female C57BL/6 mice $\left(t_{(12)}=3.380, p=0.0055\right)$ (Table 2). Moreover, in contrast to males, peripheral administration of the $\kappa$-opioid receptor agonist had no effect on the tail withdraw latency at any of the doses tested $\left(F_{(2,19)}=1.97, p=0.17\right)$ (Table 2). Together, these data demonstrate that male and female prairie voles require higher doses of nor-BNI compared to rats and mice for behavioral studies.

\section{$\kappa$-Opioid and $\mu$-opioid receptor binding patterns in prairie voles}

The peripheral manipulations of selective aggression described above demonstrate that $\kappa$ - but not $\mu$-opioid receptors mediate this behavior. To ultimately identify the central location of $\kappa$-opioid receptor regulation of selective aggression, it was first necessary to determine the distribution of opioid receptors within prairie vole brains. Since very limited knowledge exists with respect to opioid receptor distributions in the vole brain (Insel and Shapiro, 1992; Burkett et al., 2011), we conducted a detailed analysis of $\mu$ - and $\kappa$-opioid receptor binding for this species.

Overall, $\kappa$-opioid receptor binding is quite sparse compared to $\mu$-opioid receptor expression (compare Figs. 5, 6). However, consistent with other species, including humans (Mansour et al., 1987, 1988; Quirion et al., 1987), there is dense $\kappa$-opioid receptor binding throughout the striatum. This distribution pattern is similar to that of other rodents (guinea pig, rabbit, mouse, and rat) that also show dense binding within the striatum (Robson et al., 1985; Wang et al., 2011).

In rostral portions of the striatum (i.e., rostral to the corpous callosum genu), $\kappa$-opioid receptor binding is prominent within the
B
$\mathrm{G}$

I
3000
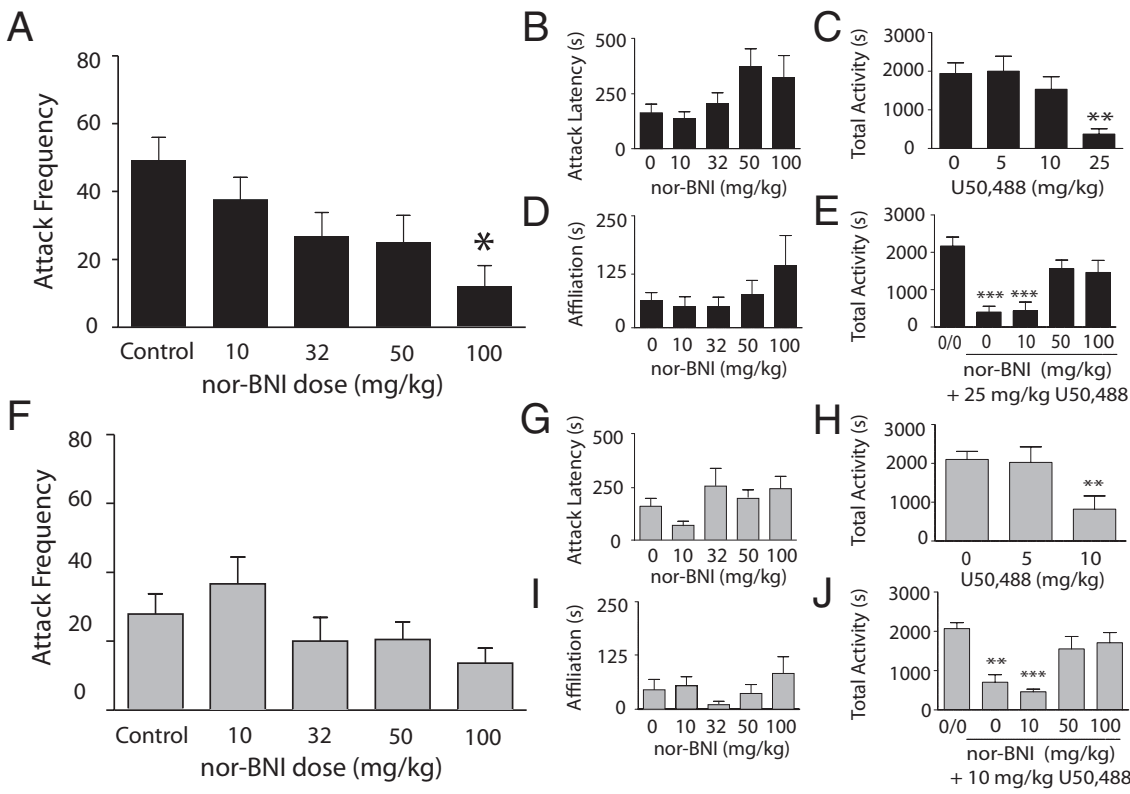

Figure 3. Peripheral administration of a $\kappa$-opioid receptor antagonist has sex-specific effects on selective aggression. $A, B, D$,
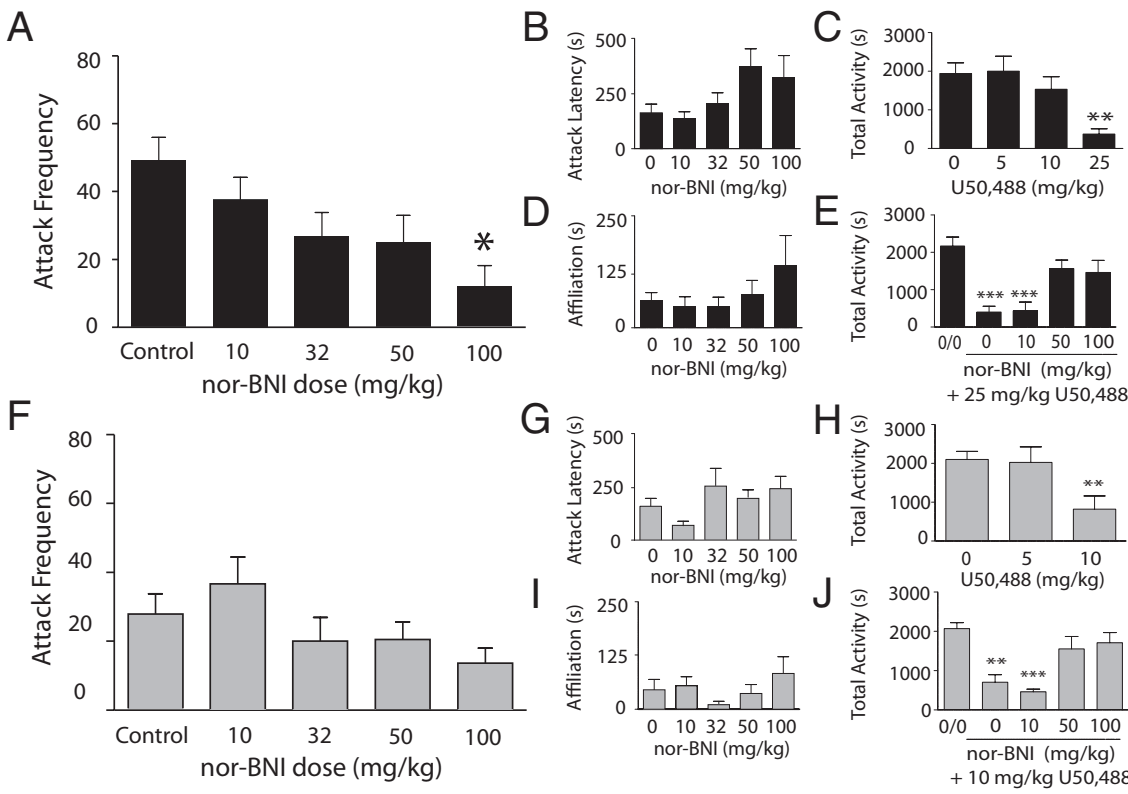

highest dose of the $\kappa$-opioid receptor antagonist nor-BNI significantly decreased aggression in pair-bonded males without

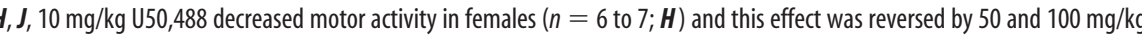
nor-BNI $(n=6 /$ group; $J) .{ }^{*} p<0.05 ;{ }^{* *} p<0.005 ;{ }^{* * *} p<0.0005$. Error bars indicate mean \pm SEM.

A
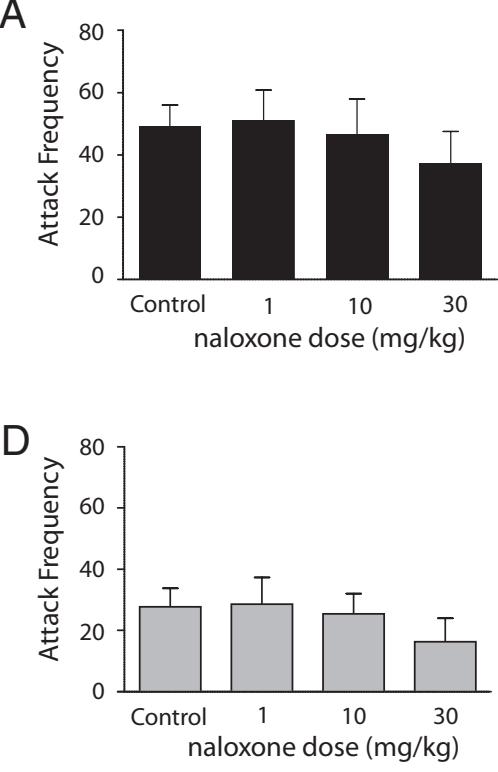

Figure 4. $\quad \mu$-0pioid receptors do not regulateselective aggression in prairie voles. $\boldsymbol{A}$-C, Peripheral administration of the $\mu$-opioid receptor antagonist, naloxone, had no effect on selective aggression, attack latency $(\boldsymbol{B})$, or affiliative behavior $(n=10$ to $11 ; \boldsymbol{C})$. D-F, Similarly, peripheral administration of naloxone failed to block aggression in pair-bonded females and had no effect on attack latency $(\boldsymbol{E})$ or affiliation levels $(n=10$ to $12 ; \boldsymbol{F})$. Error bars indicate mean \pm SEM

dorsal striatum and very dense within the ventral striatum, in particular, the NAc shell and olfactory tubercle (OT) (Fig. 5A). There is also $\kappa$-opioid receptor binding in the claustrum at this rostrocaudal level (Fig. 5A). Within more caudal regions of the striatum (nearing the genu of the corpus callosum), $\kappa$-opioid receptor binding within 
A

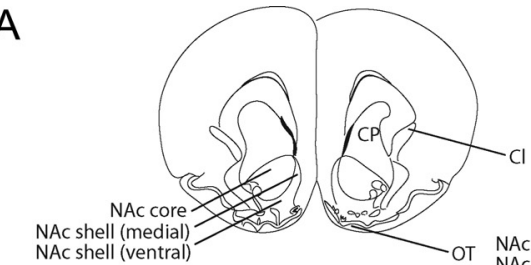

B

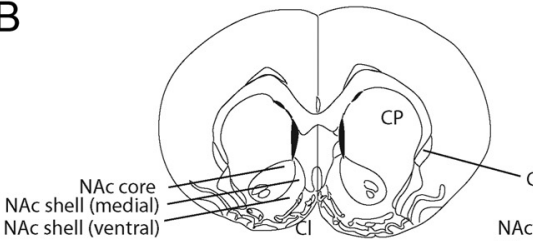

C

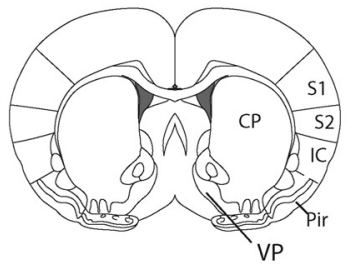

D

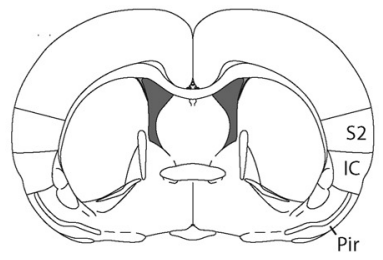

E

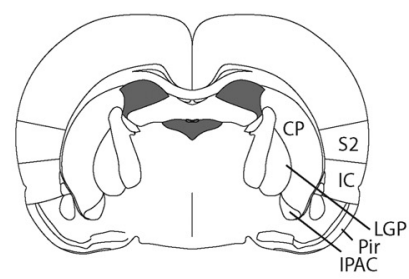

$\mathrm{F}$

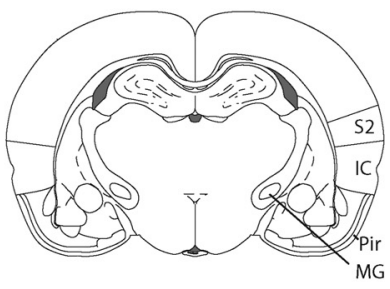

G

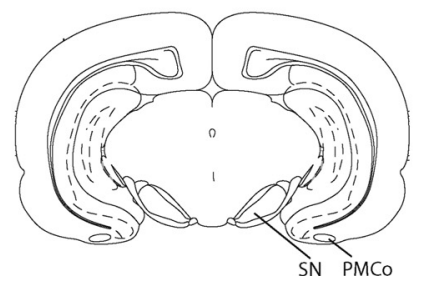

Figure 5. $\boldsymbol{A}-\boldsymbol{G}$, Distribution of $\kappa$-opioid receptors in prairie voles. $\mathrm{Cl}$, Claustrum; $\mathrm{CP}$, caudate-putamen; $\mathrm{IC}$, insular cortex; IPAC, interstital nucleus of the posterior limb of the anterior commissure; LGP, lateral globus pallidus; MG, medial geniculate nucleus; PMCo, posterior medial cortical amygdala; Pir, piriform cortex; S1, primary somatosensory cortex; S2, secondary somatosensory cortex; SNC, substantia nigra compacta; SNR, substantia nigra reticulata. the dorsal striatum is less pronounced (particularly within the dorsomedial striatum), whereas binding within the NAc shell and OT remains quite dense (Fig. $5 B$ ).

There is also a moderate level of $\kappa$-opioid receptor binding within the rostral VP (Fig. 5C,D), which is notable since this region is important for vasopressin regulation of pair bonding ( $\mathrm{Lim}$ and Young, 2004). $\kappa$-Opioid receptor binding is also present in caudal VP as well as the external globus pallidus (also known as the dorsal pallidum) (Fig. $5 E$ ). In contrast to rats, prairie voles do not have high densities of $\kappa$-opioid receptor binding in the hypothalamus (Robson et al., 1985). Additionally, $\kappa$-opioid receptors are quite strongly expressed within the substantia nigra pars reticulata (Fig. 5G) and posterior medial cortical amygdala (Fig. 5G). Finally, within cortical regions, light $\kappa$-opioid receptor binding occurs in the insular cortex and regions of the somatosensory cortex (Fig. 5A-F). Overall, these data provide additional data showing the tremendous species-specific variation in $\kappa$-opioid receptor binding patterns among rodent species. While rats and mice show very high densities in the hypothalamus and midbrain, and guinea pigs show very high levels in the striatum and cortex (Robson et al., 1985), $\kappa$-opioid receptor binding in prairie voles is most dense in the striatum and substantia nigra.

Relative to $\kappa$-opioid receptor expression, $\mu$-opioid receptors are much more widely spread throughout the prairie vole brain. A previous study provided a very cursory initial description of $\mu$-opioid receptor distributions for prairie voles (Insel and Shapiro, 1992), and a more recent study described the distribution of $\mu$-opioid receptors within the striatum (Burkett et al., 2011). Here, we significantly extend these previous findings by providing the first description of $\mu$-opioid receptor binding throughout the prairie vole brain (Fig. 6). Within the rostral striatum there is dense $\mu$-opioid receptor binding in the dorsal striatum as well as the NAc core and NAc shell (Fig. 6). Unlike $\kappa$-opioid receptors, there is no $\mu$-opioid receptor binding in the claustrum or olfactory tubercle (Fig. 6A,B). Importantly, as in other rodent species (Pert et al., 1976; Herkenham and Pert, 1981; Gerfen and Young, 1988; Mansour et al., 1994; Brown et al., 2002; Crittenden and Graybiel, 2011), a clear patch-matrix pattern of $\mu$-opioid receptor distribution can be seen throughout the striatum (Fig. $6 A-C)$. Voles also show typical variability in patch size, and most patches are located 
A
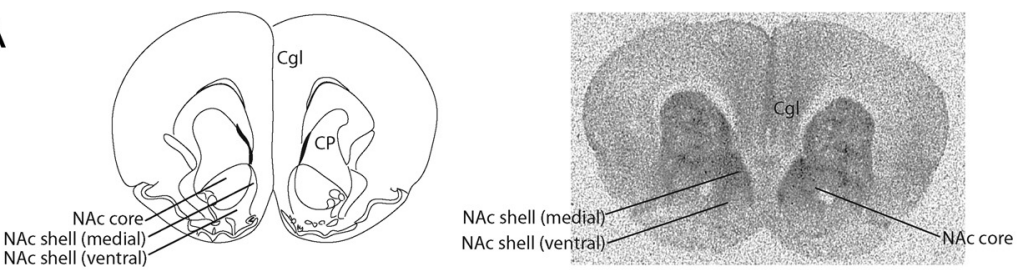

B

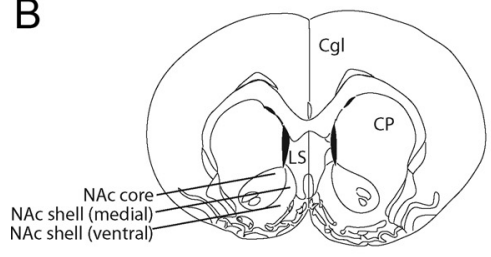

C

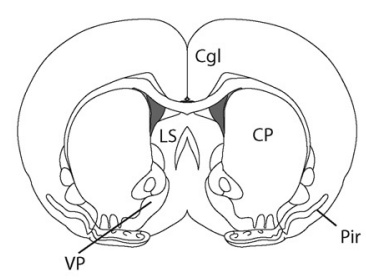

D

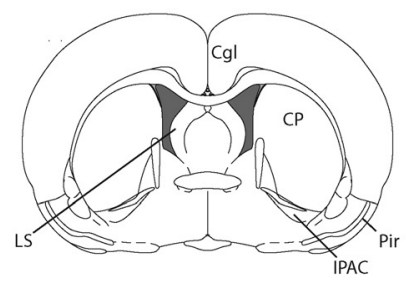

E

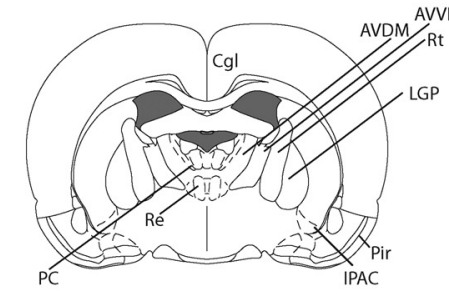

$\mathrm{F}$

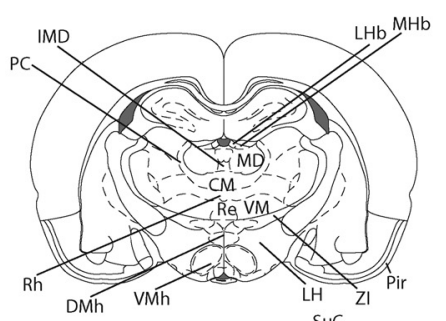

G

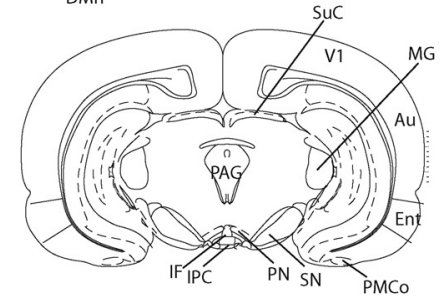

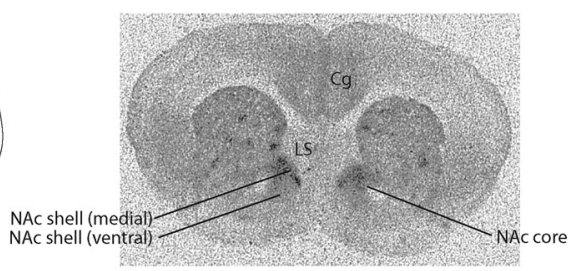
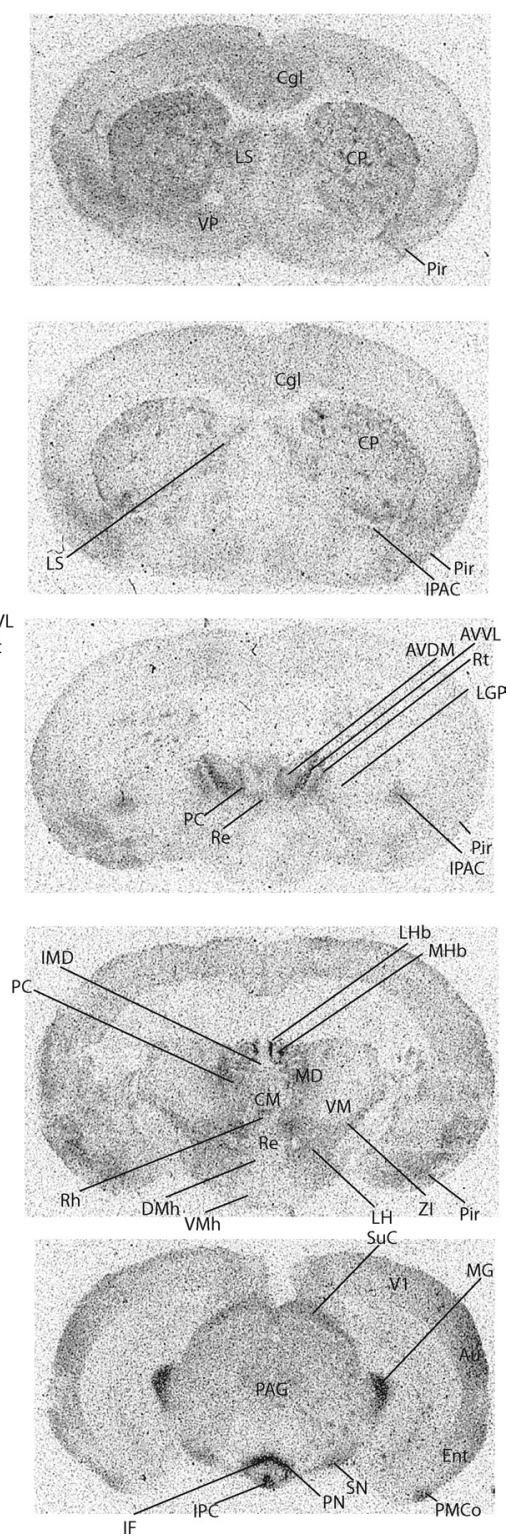

Figure 6. $A-G$, Distribution of $\mu$-opioid receptors in prairie voles. Au, Auditory cortex; AVVL, anteroventral thalamic nucleus; AVDM, anteroventral thalamic nucleus; Cgl, cingulate cortex; CM, central medial thalamic nucleus; $C P$, caudate-putamen; DMh, dorsomedial hypothalamic nucleus; Ent, entorhinal cortex; IF, interfascicular nucleus; IMD, intermediodorsal thalamic nucleus; IPAC, interstital nucleus of the posterior limb of the anterior commissure; IPC, interpeduncular nucleus, caudal subnucleus; LGP, lateral globus pallidus; LH, lateral hypothalamic area; LHb, lateral habenular nucleus; LS, lateral septum; MD, medial dorsal nucleus; MG, medial geniculate nucleus; MHb, medial habenular nucleus; NAc, nucleus accumbens; PAG, periaqueductal gray; PMCo, posterior medial cortical amygdala; PC, paracentral thalamic nucleus; Pir, piriform cortex; PN, paranigral nucleus of the VTA;

in the dorsal striatum. There is also variability of $\mu$-opioid receptor density in the ventral striatum, including robust $\mu$-opioid receptor binding in the dorsomedial NAc shell (Fig. 6B). In contrast to a previous study which claimed that $\mu$-opioid receptor binding was found within the VP (Insel and Shapiro, 1992), we saw no $\mu$-opioid receptor binding within this region (Fig. $6 C, D$ ). Moderate $\mu$-opioid receptor binding was present in the lateral septum, which is of interest because this region is involved in pair bonding (Fig. 6B,C) (Liu et al., 2001). This binding pattern contrasts that of other rodent species, such as rats, who have $\mu$-opioid receptors in the medial septum, but not in the lateral septum (Mansour et al., 1987). $\mu$-Opioid receptor binding was also seen in the interstital nucleus of the posterior limb of the anterior commissure, the amygdala/striatum transition zone (Fig. $6 D, E$ ), and the endopiriform nucleus (Fig. 6).

Consistent with rats, $\mu$-opioid binding within the hypothalamus is light and is present in the ventromedial nucleus, dorsomedial nucleus, and lateral hypothalamic area (Fig. 6F) (Mansour et al., 1987). The general distribution of $\mu$-opioid receptors in the thalamus overlaps with that of rats (Mansour et al., 1987) and can be seen in the mediodorsal, intermediodorsal, centromedial, paracentral, rhomboid, reuniens, and ventromedial thalamic nuclei, as well as light opioid receptor binding within the zona incerta (Fig. 6E,F). There is dense $\mu$-opioid receptor binding within the medial habenula and light $\mu$-opioid receptor binding within the lateral habenula and fasciculus retroflexus of the habenula (Fig. 6F). There is also substantial $\mu$-opioid receptor binding in the posterior medial cortical amygdaloid nucleus of the midbrain (Fig. $6 G$ ). $\mu$-Opioid receptor binding is also densely expressed within sensory processing systems, the superior colliculus (visual) and medial geniculate nucleus (auditory) (Fig. 6G). There is very dense expression of $\mu$-opioid receptors within subregions of the ventral tegmental area including the paranigral nucleus (Fig. 6G) and the caudal and lateral interpeduncular nuclei (Fig. $6 G$ ), and additional binding within the medial nuclei of the $\mathrm{A} 10$ region, such as the interfascicular

Re, reuniens thalamic nucleus; $\mathrm{Rh}$, rhomboid thalamic nucleus; SN, substantia nigra; SuC, suprachiasmatic nucleus; V1, primary visual cortex, lateral area; VM, ventromedial thalamic nucleus; Zl, zona incerta. 
A v
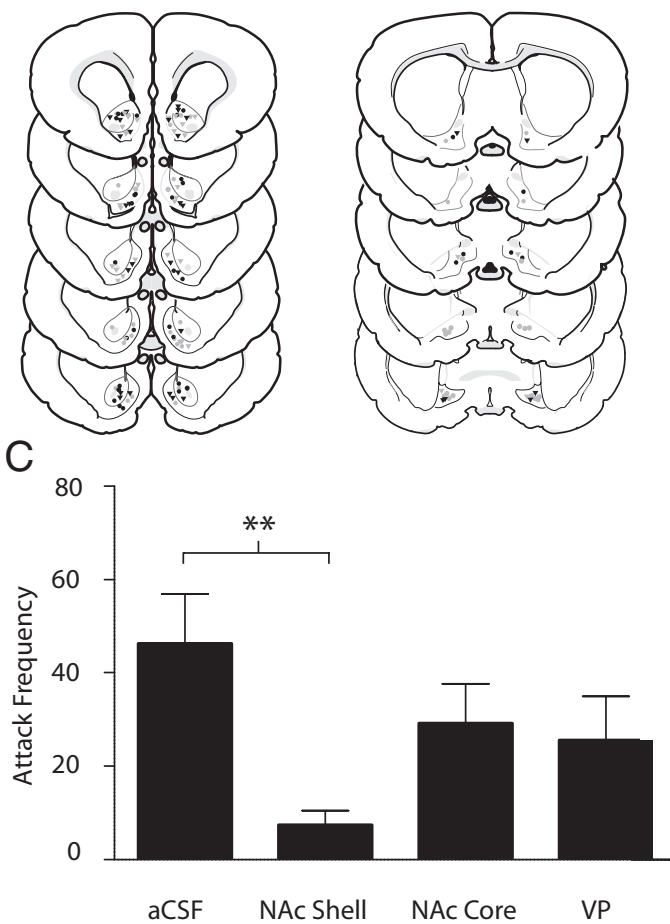

$\mathrm{F}$

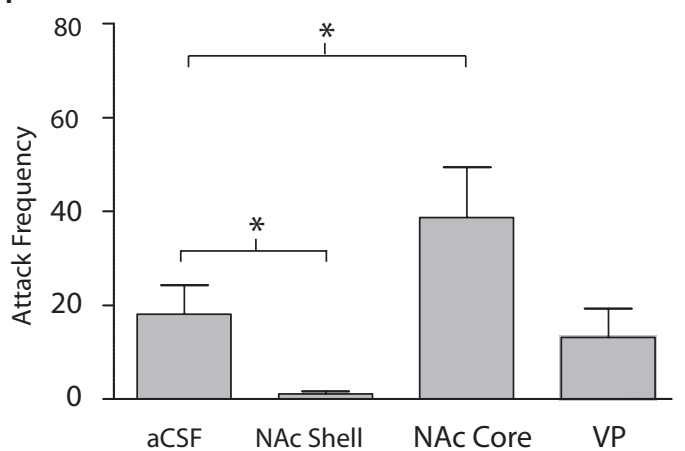

B

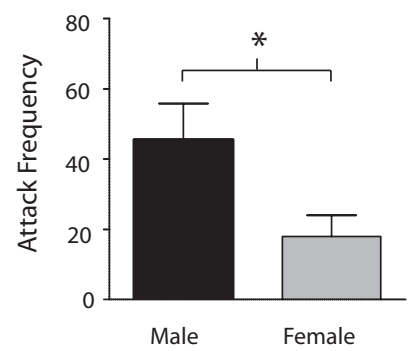

$\mathrm{D}$

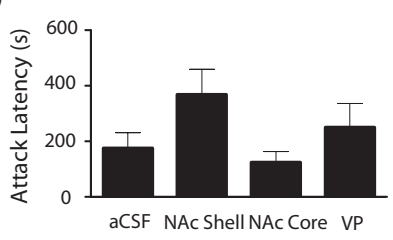

E

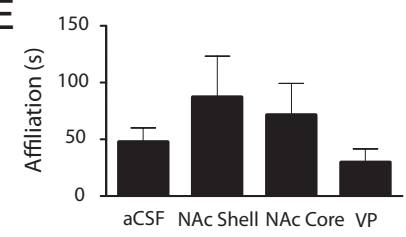

G

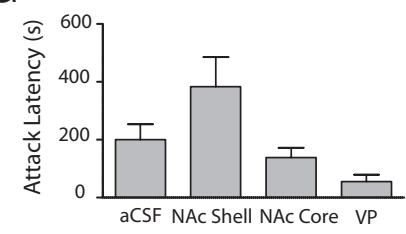

$\mathrm{H}$

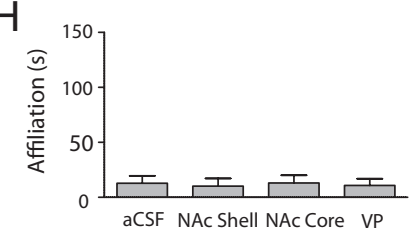

Figure 7. $\kappa$-Opioid receptors within the NAC shell mediate selective aggression. $\boldsymbol{A}$, Sites of injections of ACSF and the $\kappa$-opioid receptor antagonist nor-BNI. $\boldsymbol{B}$, Consistent with data from peripheral experiments, aggression in males is significantly higher in pair-bonded males $(n=16)$ than females $(n=16)$. C, Injections of nor-BNl into the NAc shell significantly decreased aggression compared to control injections and injections of nor-BNI in the NAc core. $\boldsymbol{D}, \boldsymbol{E}$, Additionally, nor-BNI in the NAc shell trended toward increasing attack latency and had no effect on affiliation levels in males $(n=6$ to $8 ; \boldsymbol{E})$. $\boldsymbol{F}$, Blockade of $\kappa$-opioid receptors in the NAc shell and core had opposing effects on aggression levels in females. Injections of nor-BNI in the NAc shell significantly decreased aggression levels, while injections of nor-BNI in the NAc core increased aggression levels compared to controls. $\boldsymbol{G}, \boldsymbol{H}$, No effects on attack latency $(\boldsymbol{G})$ or affiliation levels $(\boldsymbol{H})$ occurred in females $(n=6$ to 8$) .{ }^{*} p<0.05 ;{ }^{* *} p<0.005$. Error bars indicate mean \pm SEM.

Table 4. Number of cage crosses in home cage $1 \mathrm{~h}$ following site-specific injection

\begin{tabular}{llllll}
\hline & ACSF & nor-BNI & & CTAP \\
\cline { 3 - 4 } & NAc & VP & NAc core & NAc shell & NAc shell \\
\hline Male & $15.7 \pm 2.2$ & $13.0 \pm 4.1$ & $21.4 \pm 6.9$ & $12.0 \pm 4.1$ & $14.2 \pm 5.3$ \\
Female & $26.9 \pm 4.2$ & $16.2 \pm 5.9$ & $22.0 \pm 10.8$ & $16.3 \pm 4.1$ & $13.6 \pm 7.7$ \\
\hline
\end{tabular}

Site-specific administration of nor-BNI or CTAP had no significant effect on the locomotor activity of male or female prairie voles.

nucleus (Fig. $6 G$ ). There is only light binding within the periaqueductal gray and substantia nigra, which is consistent with other rodent species (Mansour et al., 1988; Laprairie and Murphy, 2009) (Fig. $6 G$ ). Similar to rabbits and guinea pigs, very little $\mu$-opioid receptor binding is seen in the hippocampus (Robson et al., 1985).
Finally, within cortical regions, $\mu$-opioid receptor binding occurs in the cingulate, entorhinal, and striate cortices (Fig. 6G).

\section{Region-specific $\kappa$ regulation of selective aggression}

The peripheral behavioral pharmacology experiments described above indicate that $\kappa$-but not $\mu$-opioid receptors mediate selective aggression. However, it is difficult to interpret data resulting from peripheral injections of antagonists because this manipulation blocks receptors globally in both the peripheral nervous system and the CNS (Wittert et al., 1996). Furthermore, opioid receptors are distributed across many brain regions that differ greatly in their regulation of behavior (Mansour et al., 1987, 1988, 1994). In prairie voles, $\kappa$-opioid receptors are densely expressed within two brain regions that are very important for pair bonding, the NAc and VP (Fig. 5). To determine whether $\kappa$-opioid receptors within these brain regions mediate selective-aggression, we selectively blocked $\kappa$-opioid receptors within these regions (Fig. 7A) of pair-bonded prairie voles before resident-intruder tests and measured the corresponding effects on selective aggression.

Control subjects that received aCSF infusions into the NAc shell, NAc core, or VP showed robust selective aggression, and males showed significantly higher attack frequency compared to females (Fig. $7 B)\left(t_{(30)}=2.32, p=0.03\right)$. There was no difference between control injections of aCSF between these brain regions in males $\left(F_{(2,15)}=0.68, p=0.52\right)$ or females $\left(F_{(2,15)}=1.52, p=0.26\right)$. Therefore, data from these regions were combined to generate an aCSF control group (male, $n=$ 16; female, $n=16$ ).

In males, Mann-Whitney $U$ test for nonparametric data revealed a significant decrease in aggression when $\kappa$-opioid receptors were blocked in the NAc shell $(U=20.50, p=0.008)$ (Fig. 7C). However, the $\kappa$ antagonist had no effect when infused into the NAc core $(U=46.50, p=0.55)$ or VP $(U=$ $44.00, p=0.24)$ (Fig. 7C). Site-directed infusion of nor-BNI had no effect on attack latency $(U=49.50, p=0.40)$ (Fig. $7 D)$, affiliative behavior $(U=49.00, p=0.37$ ) (Fig. $7 E)$, or locomotor activity $(U=43.50, p=0.92$ ) (Table 4$)$. Thus, site-specific behavioral pharmacology identified $\kappa$-opioid receptors within the NAc shell-a key brain region in mediating unconditioned motivational responses (Ikemoto and Panksepp, 1999; Kelley and Berridge, 2002) —as important for aversive social motivation in pair-bonded prairie voles.

In contrast to the sex differences following global blockade of $\kappa$-opioid receptors (Fig. 3), blockade of $\kappa$-opioid receptors within the NAc shell $(U=21.00, p=0.02)$ also prevented selective aggression in females. However, unlike in males, nor-BNI 
Table 5. Mean concentration of plasma corticosteroid (nanograms per milliliter) in pair-bonded prairie voles treated with either saline or nor-BNI $1 \mathrm{~h}$ prior to a $10 \mathrm{~min}$ resident-intruder test

\begin{tabular}{llll}
\hline & Saline & $32 \mathrm{mg} / \mathrm{kg}$ & $100 \mathrm{mg} / \mathrm{kg}$ \\
\hline Male & $1794.0 \pm 163.4$ & $2093.0 \pm 170.5$ & $1572.0 \pm 204.6$ \\
Female & $2106.0 \pm 213.2$ & $1986.0 \pm 209.1$ & $2821.0 \pm 257.1$ \\
\hline
\end{tabular}

Peripheral administration of nor-BNI had no significant effect on plasma corticosterone levels in male or female prairie voles.

Table 6. Mean concentration of plasma corticosteroid (nanograms per milliliter) in pair-bonded prairie voles receiving site specific injections of either ACSF or nor-BNI into the NAc $1 \mathrm{~h}$ prior to the resident-intruder test

\begin{tabular}{llll}
\hline & ACSF & nor-BNI & \\
\cline { 3 - 4 } & NAc & NAc shell & NAc core \\
\hline Male & $1636.0 \pm 171.1$ & $1556.0 \pm 188.6$ & $1842.0 \pm 251.6$ \\
Female & $2178.0 \pm 263.3$ & $2332.0 \pm 191.5$ & $1605.0 \pm 334.0$ \\
\hline
\end{tabular}

Site-specific administration of nor-BNI into the NAc shell or core had no significant effect on plasma corticosterone levels in male or female prairie voles.

injections into the NAc core significantly increased this behavior (Fig. $7 F)(U=20.5, p=0.05)$. As with males, $\kappa$-opioid receptor blockade within the VP had no effect on selective aggression in females $(U=45.50, p=0.88)$. In females, central infusions of nor-BNI showed no significant effects on attack latency $(U=$ 32.00, $p=0.15)$ (Fig. $7 G)$, affiliation levels $(U=32.00, p=0.82)$ (Fig. $7 H)$, or locomotor behavior $(U=33.50, p=0.32$ ) (Table 4). Together, these data show that $\kappa$-opioid receptors within the NAc shell mediate selective aggression in both male and female prairie voles.

The $\kappa$-opioid receptor antagonist used in this study, nor-BNI, also has affinity for $\mu$-opioid receptors initially following its delivery (Endoh et al., 1992). Thus, our site-directed nor-BNI data alone do not rule out the possible involvement of $\mu$-opioid receptors within the NAc shell. To test whether the reduction of selective aggression by nor-BNI was due to blockade of $\mu$-opioid receptors, a separate experiment was conducted in which the highly selective $\mu$-opioid receptor antagonist, CTAP (Crain and Shen, 1992; Nestler, 1993), was infused into the NAc shell before resident-intruder testing. Consistent with the peripheral study using naloxone, blockade of $\mu$-opioid receptors directly in the NAc shell had no effect on selective aggression in males $(U=$ 35.00, $p=0.36)$ or females $(U=32.50, p=0.56$; data not shown).

Finally, since our data indicate that $\kappa$-opioid receptors within the NAc shell mediate selective aggression through modulation of aversive social motivation, and aversive stimuli are known to increase corticosterone signaling, we determined whether blockade of $\kappa$-opioid receptors alters selective aggression indirectly though a reduction in corticosterone (DeVries et al., 1996; Bosch et al., 2009). As determined previously, plasma corticosterone levels of male and female prairie voles were high compared to those in other rodent species (DeVries et al., 1997; Taymans et al., 1997; Campbell et al., 2009) (Table 5). Consistent with studies in other rodent species (McLaughlin et al., 2006b), nor-BNI had minimal to no effect on plasma corticosterone levels. In males, there was no difference between the plasma corticosterone levels of control subjects and those that had received peripheral norBNI $\left(F_{(2,26)}=2.06, p=0.15\right)$ (Table 5$)$ or nor-BNI infused centrally $\left(F_{(2,23)}=0.42, p=0.66\right)$ (Table 6). In females, due to a slight increase in corticosterone following peripheral nor-BNI, the overall ANOVA for subjects in the peripheral study was significant $\left(F_{(2,28)}=3.69, p=0.04\right)$ (Table 5), but post hoc tests revealed no significant differences between control subjects and those treated with nor-BNI. Similar to males, there was no difference in plasma corticosterone levels between females who had received site-specific administration of aCSF or nor-BNI in the NAc core or shell $\left(F_{(2,22)}=1.52, p=0.24\right)$ (Table 6). Together, these data suggest that nor-BNI does not reduce selective aggression through changes in corticosterone signaling.

\section{Discussion}

While sexually naive prairie voles are initially highly affiliative toward novel conspecifics, once pair bonded, they show selective aggression toward unfamiliar conspecifics, and this is indicative of mate guarding behavior necessary for pair bond maintenance. Mate guarding is adaptive for males because it helps to ensure paternity (Stehn and Jannett, 1981; Heske and Nelson, 1984; Wolff and Dunlap, 2002). In the laboratory, this behavior is studied using residentintruder tests of selective aggression (Carter and Getz, 1993), and this represents a circumstance in which novel social stimulation generates negatively valenced motivational behavior, aggressive rejection, that is herein regarded as "aversive." Here, we demonstrate that blockade of $\kappa$-opioid receptors (known to mediate aversion) (Mucha and Herz, 1985; Pfeiffer et al., 1986), but not $\mu$-opioid receptors (known to mediate reward and positive hedonics) (Weeks, 1962; Bozarth and Wise, 1981), prevents selective aggression. These effects are specific to the NAc shell, a component of brain motivational circuitry that is critical for neural processing of both social bonding (Li and Fleming, 2003; Champagne et al., 2004; Aragona et al., 2006; Aragona and Wang, 2007) and unconditioned incentives, including those of an aversive nature (Kalivas and Duffy, 1995; Ikemoto and Panksepp, 1999; Kelley and Berridge, 2002; Everitt and Robbins, 2005; Becker, 2009). As such, the current data suggest that $\kappa$-opioid receptors within this region may facilitate the tagging of social stimuli as aversive and cause novel conspecifics to be aggressively rejected.

\section{$\kappa$-Opioid receptors mediate pair bond maintenance}

Peripheral blockade of $\kappa$-opioid (but not $\mu$-opioid) receptors prevented aversive social motivation in pair-bonded male prairie voles as indicated by a decrease in selective aggression. It is not surprising that peripheral blockade of $\mu$-opioid receptors failed to inhibit selective aggression since previous studies have demonstrated that blockade of these receptors is aversive (van Ree et al., 1999; Kenny et al., 2006; Le Merrer et al., 2009). In contrast to negative affective states induced by $\mu$-opioid-receptor blockade, activation of these receptors is associated with positive hedonics and mediates the rewarding properties of positive social incentives such as play and contact comfort (Panksepp et al., 1980; Vanderschuren et al., 1995; Trezza et al., 2011). Moreover, activation of $\mu$-opioid receptors is important for the early stages of pair bond formation, as blockade of these receptors within the striatum inhibits the formation of a partner preference (Burkett et al., 2011). This is especially interesting given the relationship between $\mu$-opioid receptors and $\mathrm{D}_{2}$-like receptors, which also facilitate pair bond formation (Gingrich et al., 2000; Aragona et al., 2006). Enkephalin, an endogenous ligand for $\mu$-opioid receptors, is found in $\mathrm{D}_{2}$-expressing medium spiny neurons, and stimulation of $\mathrm{D}_{2}$-like receptors increases enkephalin expression (Gerfen et al., 1990). Thus, these systems may interact to mediate social reward necessary for pair bond formation (Aragona et al., 2009), while those that mediate negative affect and stress are important for aversive social encounters that are important for maintaining the bond.

Unlike $\mu$-opioid receptors, $\kappa$-opioid receptors antagonize reward (Shippenberg et al., 1996; Carlezon and Miczek, 2010; Wee 
and Koob, 2010) and are thus a candidate to mediate aversive motivational social interactions, such as aggressive interactions. Indeed, peripheral blockade of $\kappa$-opioid receptors decreased selective aggression in male prairie voles, identifying the importance of this system in aversive social motivation. Consistent with previous studies, males were more aggressive than females (Gavish et al., 1981), and mate guarding helps ensure the male that his partner will not mate with novel males (Wolff et al., 2002). Thus, they risk devoting time and energy into offspring that are not their own if males allow another male to enter their territory. Consistent with this, we found that pregnancy was positively correlated with selective aggression, indicating that motivation to guard females increases if the reproductive potential is known to be high (Curtis, 2010).

\section{Pair bond maintenance is mediated by $\kappa$-opioid receptors in the NAc shell}

The maintenance of a pair bond requires mate guarding, which is associated with novel social stimuli to be processed as aversive. Previous studies have shown that aversive social motivation in prairie voles is mediated by activation of $\mathrm{D}_{1}$-like receptors within the NAc shell, as blockade of these receptors prevents selective aggression (Aragona et al., 2006). Here we show that $\kappa$-opioid receptors within this region are also critical for this behavior, as blockade of $\kappa$-but not $\mu$-opioid receptors specifically within the NAc shell mediate this behavior in both sexes. Given that $\kappa$-opioid receptors within the NAc shell are important for processing aversion, the present study suggests that these receptors are important for signaling negative social incentives and may be key to generating the aversive motivation toward an unfamiliar conspecifc expressed by pair-bonded prairie voles.

While the NAc shell is well known to play a critical role in the processing of unconditioned rewarding and aversive stimuli (Ikemoto and Panksepp, 1999; Ito et al., 2000; Di Chiara et al., 2004; Everitt and Robbins, 2005; Aragona et al., 2008, 2009), the neural mechanisms within this brain region that promote approach versus avoidance behavior are not well understood. For example, both unconditioned rewarding and aversive stimuli increase DA in the NAc shell (Kalivas and Duffy, 1995; Ikemoto, 2007), and this increase is associated with aspects of both approach and avoidance behaviors (Ikemoto and Panksepp, 1999; Di Chiara and Bassareo, 2007; Oleson et al., 2012). Thus, while aversive chemical stimuli have been shown to decrease DA transmission in the NAc shell (Roitman et al., 2008; Wheeler et al., 2011), there are many conditions in which DA release in the NAc shell is critical for the attribution of motivational salience to unconditioned salient stimuli regardless of the valence (Kelley and Berridge, 2002). While recent data have demonstrated that different subsets of DA containing neurons within the VTA are activated by rewarding versus aversive stimuli (Brischoux et al., 2009; Matsumoto and Hikosaka, 2009; Bromberg-Martin et al., 2010; Lammel et al., 2011), it has yet to be determined how this may be associated with social incentives. The present study suggests that for aversive motivation, $\kappa$-opioid receptor activation is also necessary to tag a conspecific with aversive motivational salience. Indeed, in addition to enhancing DA release within the NAc shell, exposure to stress is known to increase prodynorphin signaling (Chartoff et al., 2009) and activation of $\kappa$-opioid receptors within this region (Land et al., 2008). Together, data from the current study and previously published work suggest that novel conspecific exposure to pair-bonded voles increases DA transmission within the NAc shell, which then activates $D_{1}$-like receptors that may promote dynorphin release (Gerfen et al., 1991).
Subsequent $\kappa$-opioid receptor activation may then directly facilitate the perception of the stimulus as aversive, and continued $\kappa$-opioid receptor activation will then decrease DA transmission (Heijna et al., 1990; Spanagel et al., 1992), and this may be involved in the termination of the aggressive interaction via DA regulation over general motivation (Kelley and Berridge, 2002).

While blockade of $\kappa$-opioid receptors within the NAc shell decreased selective aggression in both sexes, blockade of these receptors within the NAc core had sex-specific effects. Blockade of $\kappa$-opioid receptors within the NAc core increased aggression in females, but had no effect on the behavior of males. Previous studies suggest that DA transmission within this region is not important for pair bonding (Aragona et al., 2006). However, females were not studied in these previous experiments (Aragona et al. 2006), and since the NAc core receives direct input from the NAc shell (van Dongen et al., 2005), it is possible that increased DA transmission in the NAc shell drives core-mediated behavior important for pair bonding in females. Studies using rats have indeed implicated the NAc core in sex differences in other motivated behavior (van Haaren and Meyer, 1991; Li et al., 2004; Wissman et al., 2011). However, additional experiments in voles are needed to determine whether the NAc core is important for female pair bonding.

\section{Conclusion}

Although negative affective states induced by $\kappa$-opioid receptor activation are usually associated with maladaptive conditions such as depression (Shirayama et al., 2004; Carlezon et al., 2006; Chartoff et al., 2011), anxiety (Bruchas et al., 2007; Knoll et al., 2007; Land et al., 2008), or drug-related behaviors (Bruchas et al., 2010, 2011; Schindler et al., 2010; Walker et al., 2011), acute activation of this system evolved to signal avoidance of potentially harmful stimuli (Amit and Galina, 1988; Teskey and Kavaliers, 1988; Yamada and Nabeshima, 1995). This suggests that $\kappa$-opioid receptor activation plays a critical role in encoding aversive properties of environmental stimuli. A similar phenomenon may also occur in pair-bonded voles in that activation of $\kappa$-opioid receptors may signal when a social stimulus should be avoided or prevented from entering a home territory. Thus, activation of aversive processing systems has adaptive properties, and the neurobiology of aversive social motivation can be reliably studied using prairie vole pair bonding. Such studies are important because neural mechanisms that evolved to invigorate adaptive behavioral responses to aversive stimuli can also negatively impact mental health under conditions of chronic or abnormal activation.

\section{References}

Amit Z, Galina ZH (1988) Stress induced analgesia plays an adaptive role in the organization of behavioral responding. Brain Res Bull 21:955-958.

Aragona BJ, Wang Z (2007) Opposing regulation of pair bond formation by cAMP signaling within the nucleus accumbens shell. J Neurosci $27: 13352-13356$

Aragona BJ, Wang Z (2009) Dopamine regulation of social choice in a monogamous rodent species. Front Behav Neurosci 3:15.

Aragona BJ, Liu Y, Curtis JT, Stephan FK, Wang Z (2003) A critical role for nucleus accumbens dopamine in partner-preference formation in male prairie voles. J Neurosci 23:3483-3490.

Aragona BJ, Liu Y, Yu YJ, Curtis JT, Detwiler JM, Insel TR, Wang Z (2006) Nucleus accumbens dopamine differentially mediates the formation and maintenance of monogamous pair bonds. Nat Neurosci 9:133-139.

Aragona BJ, Cleaveland NA, Stuber GD, Day JJ, Carelli RM, Wightman RM (2008) Preferential enhancement of dopamine transmission within the nucleus accumbens shell by cocaine is attributable to a direct increase in phasic dopamine release events. J Neurosci 28:8821-8831. 
Aragona BJ, Day JJ, Roitman MF, Cleaveland NA, Wightman RM, Carelli RM (2009) Regional specificity in the real-time development of phasic dopamine transmission patterns during acquisition of a cue-cocaine association in rats. Eur J Neurosci 30:1889-1899.

Becker JB (2009) Sexual differentiation of motivation: a novel mechanism? Horm Behav 55:646-654.

Beeman EA (1947) The effect of male hormone on aggressive behavior in mice. Physiol Zool 20:373-405.

Bosch OJ, Nair HP, Ahern TH, Neumann ID, Young LJ (2009) The CRF system mediates increased passive stress-coping behavior following the loss of a bonded partner in a monogamous rodent. Neuropsychopharmacology 34:1406-1415.

Bowler CM, Cushing BS, Carter CS (2002) Social factors regulate femalefemale aggression and affiliation in prairie voles. Physiol Behav 76:559-566.

Bozarth MA, Wise RA (1981) Heroin reward is dependent on a dopaminergic substrate. Life Sci 29:1881-1886.

Brent PJ (1993) Behavioural effect of pretreatment with opioid antagonists and sigma binding site ligands on the abnormal motor response produced by the kappa opioid agonist U50,488H in guinea pigs. Neuropharmacology 32:751-760.

Brischoux F, Chakraborty S, Brierley DI, Ungless MA (2009) Phasic excitation of dopamine neurons in ventral VTA by noxious stimuli. Proc Natl Acad Sci U S A 106:4894-4899.

Broadbear JH, Negus SS, Butelman ER, de Costa BR, Woods JH (1994) Differential effects of systemically administered nor-binaltorphimine (nor-BNI) on kappa-opioid agonists in the mouse writhing assay. Psychopharmacology (Berl) 115:311-319.

Bromberg-Martin ES, Matsumoto M, Hikosaka O (2010) Dopamine in motivational control: rewarding, aversive, and alerting. Neuron 68:815-834.

Bronson FH, Desjardins C (1969) Aggressive behavior and seminal vesicle function in mice: differential sensitivity to androgen given neonatally. Endocrinology 85:971-974.

Brown LL, Feldman SM, Smith DM, Cavanaugh JR, Ackermann RF, Graybiel AM (2002) Differential metabolic activity in the striosome and matrix compartments of the rat striatum during natural behaviors. J Neurosci 22:305-314.

Bruchas MR, Land BB, Aita M, Xu M, Barot SK, Li S, Chavkin C (2007) Stress-induced p38 mitogen-activated protein kinase activation mediates kappa-opioid-dependent dysphoria. J Neurosci 27:11614-11623.

Bruchas MR, Land BB, Chavkin C (2010) The dynorphin/kappa opioid system as a modulator of stress-induced and pro-addictive behaviors. Brain Res 1314:44-55.

Bruchas MR, Schindler AG, Shankar H, Messinger DI, Miyatake M, Land BB, Lemos JC, Hagan CE, Neumaier JF, Quintana A, Palmiter RD, Chavkin C (2011) Selective p38alpha MAPK deletion in serotonergic neurons produces stress resilience in models of depression and addiction. Neuron 71:498-511.

Burkett JP, Spiegel LL, Inoue K, Murphy AZ, Young LJ (2011) Activation of mu-opioid receptors in the dorsal striatum is necessary for adult social attachment in monogamous prairie voles. Neuropsychopharmacology 36:2200-2210.

Butelman ER, Negus SS, Ai Y, de Costa BR, Woods JH (1993) Kappa opioid antagonist effects of systemically administered nor-binaltorphimine in a thermal antinociception assay in rhesus monkeys. J Pharmacol Exp Ther 267:1269-1276.

Buwalda B, Scholte J, de Boer SF, Coppens CM, Koolhaas JM (2011) The acute glucocorticoid stress response does not differentiate between rewarding and aversive social stimuli in rats. Horm Behav 61:218-226.

Campbell JC, Laugero KD, Van Westerhuyzen JA, Hostetler CM, Cohen JD, Bales KL (2009) Costs of pair-bonding and paternal care in male prairie voles (Microtus ochrogaster). Physiol Behav 98:367-373.

Carlezon WA Jr, Miczek KA (2010) Ascent of the kappa-opioid receptor in psychopharmacology. Psychopharmacology (Berl) 210:107-108.

Carlezon WA Jr, Béguin C, DiNieri JA, Baumann MH, Richards MR, Todtenkopf MS, Rothman RB, Ma Z, Lee DY, Cohen BM (2006) Depressive-like effects of the kappa-opioid receptor agonist salvinorin A on behavior and neurochemistry in rats. J Pharmacol Exp Ther 316:440-447.

Carter CS, Getz LL (1993) Monogamy and the prairie vole. Sci Am 268:100-106.

Carter CS, DeVries AC, Taymans SE, Roberts RL, Williams JR, Getz LL
(1997) Peptides, steroids, and pair bonding. Ann NY Acad Sci 807:260-272.

Champagne FA, Chretien P, Stevenson CW, Zhang TY, Gratton A, Meaney MJ (2004) Variations in nucleus accumbens dopamine associated with individual differences in maternal behavior in the rat. J Neurosci 24:4113-4123.

Chartoff E, Sawyer A, Rachlin A, Potter D, Pliakas A, Carlezon WA (2011) Blockade of kappa opioid receptors attenuates the development of depressive-like behaviors induced by cocaine withdrawal in rats. Neuropharmacology 62:167-176.

Chartoff EH, Papadopoulou M, MacDonald ML, Parsegian A, Potter D, Konradi C, Carlezon WA Jr (2009) Desipramine reduces stress-activated dynorphin expression and CREB phosphorylation in NAc tissue. Mol Pharmacol 75:704-712.

Chavkin C, James IF, Goldstein A (1982) Dynorphin is a specific endogenous ligand of the kappa opioid receptor. Science 215:413-415.

Crain SM, Shen KF (1992) After GM1 ganglioside treatment of sensory neurons naloxone paradoxically prolongs the action potential but still antagonizes opioid inhibition. J Pharmacol Exp Ther 260:182-186.

Crittenden JR, Graybiel AM (2011) Basal Ganglia disorders associated with imbalances in the striatal striosome and matrix compartments. Front Neuroanat 5:59.

Curtis JT (2010) Does fertility trump monogamy? Anim Behav 80:319-328.

Curtis JT, Wang Z (2005) Ventral tegmental area involvement in pair bonding in male prairie voles. Physiol Behav 86:338-346.

DeVries AC, DeVries MB, Taymans SE, Carter CS (1996) The effects of stress on social preferences are sexually dimorphic in prairie voles. Proc Natl Acad Sci U S A 93:11980-11984.

DeVries AC, Taymans SE, Carter CS (1997) Social modulation of corticosteroid responses in male prairie voles. Ann N Y Acad Sci 807:494-497.

Di Chiara G, Bassareo V (2007) Reward system and addiction: what dopamine does and doesn't do. Curr Opin Pharmacol 7:69-76.

Di Chiara G, Bassareo V, Fenu S, De Luca MA, Spina L, Cadoni C, Acquas E, Carboni E, Valentini V, Lecca D (2004) Dopamine and drug addiction: the nucleus accumbens shell connection. Neuropharmacology 47 [Suppl 1]:227-241.

Edwards DA (1968) Mice: fighting by neonatally androgenized females. Science 161:1027-1028

Endoh T, Matsuura H, Tanaka C, Nagase H (1992) Nor-binaltorphimine: a potent and selective kappa-opioid receptor antagonist with long-lasting activity in vivo. Arch Int Pharmacodyn Ther 316:30-42.

Everitt BJ, Robbins TW (2005) Neural systems of reinforcement for drug addiction: from actions to habits to compulsion. Nat Neurosci 8:1481-1489.

Fink S, Excoffier L, Heckel G (2006) Mammalian monogamy is not controlled by a single gene. Proc Natl Acad Sci U S A 103:10956-10960.

Firestone KB, Thompson KV, Carter CS (1991a) Female-female interactions and social stress in prairie voles. Behav Neural Biol 55:31-41.

Firestone KB, Thompson KV, Carter CS (1991b) Behavioral correlates of intra-female reproductive suppression in prairie voles, Microtus ochrogaster. Behav Neural Biol 55:363-368.

Gavish L, Carter CS, Getz LL (1981) Further evidences for monogamy in the prairie vole. Anim Behav 29:955-957.

Gavish L, Carter CS, Getz LL (1983) Male-female interactions in priairie voles. Anim Behav 31:511-517.

Gerfen CR, Young WS 3rd (1988) Distribution of striatonigral and striatopallidal peptidergic neurons in both patch and matrix compartments: an in situ hybridization histochemistry and fluorescent retrograde tracing study. Brain Res 460:161-167.

Gerfen CR, Engber TM, Mahan LC, Susel Z, Chase TN, Monsma FJ Jr, Sibley DR (1990) D1 and D2 dopamine receptor-regulated gene expression of striatonigral and striatopallidal neurons. Science 250:1429-1432.

Gerfen CR, McGinty JF, Young WS 3rd (1991) Dopamine differentially regulates dynorphin, substance $\mathrm{P}$, and enkephalin expression in striatal neurons: in situ hybridization histochemical analysis. J Neurosci 11:1016-1031.

Getz LL (1978) Speculation on social structure and population cycles of microtine rodents. Biologist 60:134-147.

Getz LL, Carter CS, Gavish L (1981) The mating system of the prairie vole, Microtus ochrogaster. Field and laboratory evidence for pair bonding. Behav Ecol Sociobiol 8:189-194. 
Getz LL, McGuire B, Pizzuto T, Hofmann JE, Frase B (1993) Social organization of the prairie vole (Microtus ochrogaster). J Mammal 74:44-58.

Gingrich B, Liu Y, Cascio C, Wang Z, Insel TR (2000) Dopamine D2 receptors in the nucleus accumbens are important for social attachment in female prairie voles (Microtus ochrogaster). Behav Neurosci 114:173-183.

Gobrogge KL, Liu Y, Young LJ, Wang Z (2009) Anterior hypothalamic vasopressin regulates pair-bonding and drug-induced aggression in a monogamous rodent. Proc Natl Acad Sci U S A 106:19144-19149.

Grimm JW, Manaois M, Osincup D, Wells B, Buse C (2007) Naloxone attenuates incubated sucrose craving in rats. Psychopharmacology (Berl) 194:537-544.

Haug M, Spetz JF, Brain PF, Mandel P (1986) Effects of naloxone administration on attack by castrated male mice on lactating intruders. Gen Pharmacol 17:493-495.

Heijna MH, Padt M, Hogenboom F, Portoghese PS, Mulder AH, Schoffelmeer AN (1990) Opioid receptor-mediated inhibition of dopamine and acetylcholine release from slices of rat nucleus accumbens, olfactory tubercle and frontal cortex. Eur J Pharmacol 181:267-278.

Herkenham M, Pert CB (1981) Mosaic distribution of opiate receptors, parafascicular projections and acetylcholinesterase in rat striatum. Nature 291:415-418.

Heske EJ, Nelson RJ (1984) Pregnancy interruption in Microtus ochrogaster: Laboratory artifact or field phenomenon? Biol Reprod 31:97-103.

Ikemoto S (2007) Dopamine reward circuitry: two projection systems from the ventral midbrain to the nucleus accumbens-olfactory tubercle complex. Brain Res Rev 56:27-78.

Ikemoto S, Panksepp J (1999) The role of nucleus accumbens dopamine in motivated behavior: a unifying interpretation with special reference to reward-seeking. Brain Res Brain Res Rev 31:6-41.

Insel TR, Shapiro LE (1992) Oxytocin receptor distribution reflects social organization in monogamous and polygamous voles. Proc Natl Acad Sci U S A 89:5981-5985.

Ito R, Dalley JW, Howes SR, Robbins TW, Everitt BJ (2000) Dissociation in conditioned dopamine release in the nucleus accumbens core and shell in response to cocaine cues and during cocaine-seeking behavior in rats. J Neurosci 20:7489-7495.

Kalivas PW, Duffy P (1995) Selective activation of dopamine transmission in the shell of the nucleus accumbens by stress. Brain Res 675:325-328.

Kelley AE, Berridge KC (2002) The neuroscience of natural rewards: relevance to addictive drugs. J Neurosci 22:3306-3311.

Kenny PJ, Chen SA, Kitamura O, Markou A, Koob GF (2006) Conditioned withdrawal drives heroin consumption and decreases reward sensitivity. J Neurosci 26:5894-5900.

Knoll AT, Meloni EG, Thomas JB, Carroll FI, Carlezon WA Jr (2007) Anxiolytic-like effects of kappa-opioid receptor antagonists in models of unlearned and learned fear in rats. J Pharmacol Exp Ther 323:838-845.

Kuzmin A, Sandin J, Terenius L, Ogren SO (2000) Dose- and timedependent bimodal effects of kappa-opioid agonists on locomotor activity in mice. J Pharmacol Exp Ther 295:1031-1042.

Lammel S, Ion DI, Roeper J, Malenka RC (2011) Projection-specific modulation of dopamine neuron synapses by aversive and rewarding stimuli. Neuron 70:855-862.

Land BB, Bruchas MR, Lemos JC, Xu M, Melief EJ, Chavkin C (2008) The dysphoric component of stress is encoded by activation of the dynorphin kappa-opioid system. J Neurosci 28:407-414.

Laprairie JL, Murphy AZ (2009) Neonatal injury alters adult pain sensitivity by increasing opioid tone in the periaqueductal gray. Front Behav Neurosci 3:31.

Le Merrer J, Becker JA, Befort K, Kieffer BL (2009) Reward processing by the opioid system in the brain. Physiol Rev 89:1379-1412.

Le Moine C, Bloch B (1995) D1 and D2 dopamine receptor gene expression in the rat striatum: sensitive cRNA probes demonstrate prominent segregation of D1 and D2 mRNAs in distinct neuronal populations of the dorsal and ventral striatum. J Comp Neurol 355:418-426.

Leyton M, Stewart J (1992) The stimulation of central kappa opioid receptors decreases male sexual behavior and locomotor activity. Brain Res 594:56-74.

Li M, Fleming AS (2003) Differential involvement of nucleus accumbens shell and core subregions in maternal memory in postpartum female rats. Behav Neurosci 117:426-445.

Li Y, Acerbo MJ, Robinson TE (2004) The induction of behavioural sensi- tization is associated with cocaine-induced structural plasticity in the core (but not shell) of the nucleus accumbens. Eur J Neurosci 20:1647-1654.

Lim MM, Young LJ (2004) Vasopressin-dependent neural circuits underlying pair bond formation in the monogamous prairie vole. Neuroscience 125:35-45.

Lindholm S, Werme M, Brené S, Franck J (2001) The selective kappa-opioid receptor agonist $\mathrm{U} 50,488 \mathrm{H}$ attenuates voluntary ethanol intake in the rat. Behav Brain Res 120:137-146.

Liu Y, Wang ZX (2003) Nucleus accumbens oxytocin and dopamine interact to regulate pair bond formation in female prairie voles. Neuroscience 121:537-544.

Liu Y, Curtis JT, Wang Z (2001) Vasopressin in the lateral septum regulates pair bond formation in male prairie voles (Microtus ochrogaster). Behav Neurosci 115:910-919.

Mabry KE, Streatfeild CA, Keane B, Solomon NG (2011) avprla length polymorphism is not associated with either social or genetic monogamy in free-living prairie voles. Anim Behav 81:11-18.

Magnan J, Paterson SJ, Tavani A, Kosterlitz HW (1982) The binding spectrum of narcotic analgesic drugs with different agonists and antagonists properties. Naunyn Schmiedebergs Arch Pharmacol 319:197-205.

Mague SD, Pliakas AM, Todtenkopf MS, Tomasiewicz HC, Zhang Y, Stevens WC Jr, Jones RM, Portoghese PS, Carlezon WA Jr (2003) Antidepressant-like effects of kappa-opioid receptor antagonists in the forced swim test in rats. J Pharmacol Exp Ther 305:323-330.

Mansour A, Khachaturian H, Lewis ME, Akil H, Watson SJ (1987) Autoradiographic differentiation of $\mathrm{mu}$, delta, and kappa opioid receptors in the rat forebrain and midbrain. J Neurosci 7:2445-2464.

Mansour A, Khachaturian H, Lewis ME, Akil H, Watson SJ (1988) Anatomy of CNS opioid receptors. Trends Neurosci 11:308-314.

Mansour A, Fox CA, Burke S, Meng F, Thompson RC, Akil H, Watson SJ (1994) $\mathrm{Mu}$, delta, and kappa opioid receptor mRNA expression in the rat CNS: an in situ hybridization study. J Comp Neurol 350:412-438.

Matsumoto M, Hikosaka O (2009) Two types of dopamine neuron distinctly convey positive and negative motivational signals. Nature 459:837-841.

McCurdy CR, Sufka KJ, Smith GH, Warnick JE, Nieto MJ (2006) Antinociceptive profile of salvinorin $\mathrm{A}$, a structurally unique kappa opioid receptor agonist. Pharmacol Biochem Behav 83:109-113.

McLaughlin JP, Marton-Popovici M, Chavkin C (2003) Kappa opioid receptor antagonism and prodynorphin gene disruption block stressinduced behavioral responses. J Neurosci 23:5674-5683.

McLaughlin JP, Li S, Valdez J, Chavkin TA, Chavkin C (2006a) Social defeat stress-induced behavioral responses are mediated by the endogenous kappa opioid system. Neuropsychopharmacology 31:1241-1248.

McLaughlin JP, Land BB, Li S, Pintar JE, Chavkin C (2006b) Prior activation of kappa opioid receptors by U50,488 mimics repeated forced swim stress to potentiate cocaine place preference conditioning. Neuropsychopharmacology 31:787-794.

Mucha RF, Herz A (1985) Motivational properties of kappa and mu opioid receptor agonists studied with place and taste preference conditioning. Psychopharmacology (Berl) 86:274-280.

Nestler EJ (1993) Cellular responses to chronic treatment with drugs of abuse. Crit Rev Neurobiol 7:23-39.

Oleson EB, Beckert MV, Morra JT, Lansink CS, Cachope R, Abdullah RA, Loriaux AL, Schetters D, Pattij T, Roitman MF, Lichtman AH, Cheer JF (2012) Endocannabinoids shape accumbal encoding of cue-motivated behavior via CB1 receptor activation in the ventral tegmentum. Neuron 73:360-373.

Ophir AG, Phelps EA, Sorin AB, Wolff JO (2008) Social but not genetic monogamy is associated with greater breeding success in prairie voles. Anim Behav 75:1143-1154

Panksepp J, Herman BH, Vilberg T, Bishop P, DeEskinazi FG (1980) Endogenous opioids and social behavior. Neurosci Biobehav Rev 4:473-487.

Peciña S, Berridge KC (2005) Hedonic hot spot in nucleus accumbens shell: where do mu-opioids cause increased hedonic impact of sweetness? J Neurosci 25:11777-11786.

Pelton JT, Kazmierski W, Gulya K, Yamamura HI, Hruby VJ (1986) Design and synthesis of conformationally constrained somatostatin analogues with high potency and specificity for mu opioid receptors. J Med Chem 29:2370-2375. 
Perreault ML, Hasbi A, O’Dowd BF, George SR (2011) The dopamine D1-D2 receptor heteromer in striatal medium spiny neurons: evidence for a third distinct neuronal pathway in Basal Ganglia. Front Neuroanat 5:31.

Pert CB, Kuhar MJ, Snyder SH (1976) Opiate receptor: autoradiographic localization in rat brain. Proc Natl Acad Sci U S A 73:3729-3733.

Pfeiffer A, Brantl V, Herz A, Emrich HM (1986) Psychotomimesis mediated by kappa opiate receptors. Science 233:774-776.

Portoghese PS, Lipkowski AW, Takemori AE (1987) Binaltorphimine and nor-binaltorphimine, potent and selective kappa-opioid receptor antagonists. Life Sci 40:1287-1292.

Quirion R, Pilapil C, Magnan J (1987) Localization of kappa opioid receptor binding sites in human forebrain using [3H]U69,593: comparison with [3H]bremazocine. Cell Mol Neurobiol 7:303-307.

Robson LE, Gillan MG, Kosterlitz HW (1985) Species differences in the concentrations and distributions of opioid binding sites. Eur J Pharmacol 112:65-71.

Roitman MF, Wheeler RA, Wightman RM, Carelli RM (2008) Real-time chemical responses in the nucleus accumbens differentiate rewarding and aversive stimuli. Nat Neurosci 11:1376-1377.

Rose KR, Gaines MS (1976) Levels of aggression in fluctuating populations of the prairie vole, microtus ochrogaster, in eastern Kansas. J Mammal 57:43-57.

Schindler AG, Li S, Chavkin C (2010) Behavioral stress may increase the rewarding valence of cocaine-associated cues through a dynorphin/ kappa-opioid receptor-mediated mechanism without affecting associative learning or memory retrieval mechanisms. Neuropsychopharmacology 35:1932-1942.

Schnur P, Walker JM (1990) Effects of U50,488H on locomotor activity in the hamster. Pharmacol Biochem Behav 36:813-816.

Schuurman T (1980) Hormonal correlates of agonistic behavior in adult male rats. Prog Brain Res 53:415-420.

Shippenberg TS, LeFevour A, Heidbreder C (1996) kappa-Opioid receptor agonists prevent sensitization to the conditioned rewarding effects of cocaine. J Pharmacol Exp Ther 276:545-554.

Shirayama Y, Ishida H, Iwata M, Hazama GI, Kawahara R, Duman RS (2004) Stress increases dynorphin immunoreactivity in limbic brain regions and dynorphin antagonism produces antidepressant-like effects. J Neurochem 90:1258-1268.

Simmons D, Self DW (2009) Role of mu- and delta-opioid receptors in the nucleus accumbens in cocaine-seeking behavior. Neuropsychopharmacology 34:1946-1957.

Sisti HM, Lewis MJ (2001) Naloxone suppression and morphine enhancement of voluntary wheel-running activity in rats. Pharmacol Biochem Behav 70:359-365.

Solomon NG, Jacquot JJ (2002) Characteristics of resident and wandering prairie voles, Microtus ochrogaster. Canadian J Zool 80:951-955.

Solomon NG, Richmond AR, Harding PA, Fries A, Jacquemin S, Schaefer RL, Lucia KE, Keane B (2009) Polymorphism at the avprla locus in male prairie voles correlated with genetic but not social monogamy in field populations. Mol Ecol 18:4680-4695.

Spanagel R, Herz A, Shippenberg TS (1992) Opposing tonically active endogenous opioid systems modulate the mesolimbic dopaminergic pathway. Proc Natl Acad Sci U S A 89:2046-2050.

Stehn RA, Jannett FJ (1981) Male-induced abortion in various microtine rodents. J Mammal 62:369-372.

Stribley JM, Carter CS (1999) Developmental exposure to vasopressin increases aggression in adult prairie voles. Dev Biol 96:12601-12604.

Taymans SE, DeVries AC, DeVries MB, Nelson RJ, Friedman TC, Castro M, Detera-Wadleigh S, Carter CS, Chrousos GP (1997) The hypothalamicpituitary-adrenal axis of prairie voles (Microtus ochrogaster): evidence for target tissue glucocorticoid resistance. Gen Comp Endocrinol 106:48-61.

Teskey GC, Kavaliers M (1988) Effects of opiate agonists and antagonists on aggressive encounters and subsequent opioid-induced analgesia, activity and feeding responses in male mice. Pharmacol Biochem Behav 31:43-52.

Trezza V, Damsteegt R, Achterberg EJ, Vanderschuren LJ (2011) Nucleus accumbens $\mu$-opioid receptors mediate social reward. J Neurosci 31:6362-6370.

Ukai M, Kameyama T (1985) Multi-dimensional analyses of behavior in mice treated with U-50,488H, a purported kappa (non-mu) opioid agonist. Brain Res 337:352-356.

Vanderschuren LJ, Niesink RJ, Spruijt BM, Van Ree JM (1995) Mu- and kappa-opioid receptor-mediated opioid effects on social play in juvenile rats. Eur J Pharmacol 276:257-266.

van Dongen YC, Deniau JM, Pennartz CM, Galis-de Graaf Y, Voorn P, Thierry AM, Groenewegen HJ (2005) Anatomical evidence for direct connections between the shell and core subregions of the rat nucleus accumbens. Neuroscience 136:1049-1071.

van Haaren F, Meyer ME (1991) Sex differences in locomotor activity after acute and chronic cocaine administration. Pharmacol Biochem Behav 39:923-927.

van Ree JM, Gerrits MA, Vanderschuren LJ (1999) Opioids, reward and addiction: an encounter of biology, psychology, and medicine. Pharmacol Rev 51:341-396.

Von Voigtlander PF, Lewis RA (1982) U-50,488, a selective kappa opioid agonist: comparison to other reputed kappa agonists. Prog Neuropsychopharmacol Biol Psychiatry 6:467-470.

Walker BM, Zorrilla EP, Koob GF (2011) Systemic kappa-opioid receptor antagonism by nor-binaltorphimine reduces dependence-induced excessive alcohol self-administration in rats. Addict Biol 16:116-119.

Wang YJ, Rasakham K, Huang P, Chudnovskaya D, Cowan A, Liu-Chen LY (2011) Sex difference in kappa-opioid receptor (KOPR)-mediated behaviors, brain region KOPR level and KOPR-mediated guanosine $5^{\prime}-O-$ (3-[35S]thiotriphosphate) binding in the guinea pig. J Pharmacol Exp Ther 339:438-450.

Wang Z, Hulihan TJ, Insel TR (1997) Sexual and social experience is associated with different patterns of behavior and neural activation in male prairie voles. Brain Res 767:321-332.

Wee S, Koob GF (2010) The role of the dynorphin-kappa opioid system in the reinforcing effects of drugs of abuse. Psychopharmacology (Berl) 210:121-135.

Weeks JR (1962) Experimental morphine addiction: method for automatic intravenous injections in unrestrained rats. Science 138:143-144

Wheeler RA, Aragona BJ, Fuhrmann KA, Jones JL, Day JJ, Cacciapaglia F, Wightman RM, Carelli RM (2011) Cocaine cues drive opposing context-dependent shifts in reward processing and emotional state. Biol Psychiatry 69:1067-1074.

Williams JR, Carter CS, Insel T (1992) Partner preference development in female prairie voles is facilitated by mating or the central infusion of oxytocin. Ann N Y Acad Sci 652:487-489.

Winslow JT, Hastings N, Carter CS, Harbaugh CR, Insel TR (1993) A role for central vasopressin in pair bonding in monogamous prairie voles. Nature 365:545-548.

Wissman AM, McCollum AF, Huang GZ, Nikrodhanond AA, Woolley CS (2011) Sex differences and effects of cocaine on excitatory synapses in the nucleus accumbens. Neuropharmacology 61:217-227.

Wittert G, Hope P, Pyle D (1996) Tissue distribution of opioid receptor gene expression in the rat. Biochem Biophys Res Commun 218:877-881.

Wolff JO, Dunlap AS (2002) Multi-male mating, probability of conception, and litter size in the prairie vole (Microtus ochrogaster). Behav Processes $58: 105-110$

Wolff JO, Mech SG, Dunlap AS, Hodges KE (2002) Mulit-male mating by paired and unpaired female prairie voles (Microtus ochrogaster). Behaviour 139:1147-1160.

Yamada K, Nabeshima T (1995) Stress-induced behavioral responses and multiple opioid systems in the brain. Behav Brain Res 67:133-145.

Young LJ, Hammock EA (2007) On switches and knobs, microsatellites and monogamy. Trends Genet 23:209-212.

Young LJ, Wang Z (2004) The neurobiology of pair bonding. Nat Neurosci 7:1048-1054

Young LJ, Winslow JT, Nilsen R, Insel TR (1997) Species differences in V1a receptor gene expression in monogamous and nonmonogamous voles: behavioral consequences. Behav Neurosci 111:599-605.

Young LJ, Wang Z, Insel TR (1998) Neuroendocrine bases of monogamy. Trends Neurosci 21:71-75.

Young LJ, Murphy Young AZ, Hammock EA (2005) Anatomy and neurochemistry of the pair bond. J Comp Neurol 493:51-57.

Zhang H, Shi YG, Woods JH, Watson SJ, Ko MC (2007) Central kappaopioid receptor-mediated antidepressant-like effects of nor-Binaltorphimine: behavioral and BDNF mRNA expression studies. Eur J Pharmacol 570:89-96.

Zhang M, Kelley AE (1997) Opiate agonists microinjected into the nucleus accumbens enhance sucrose drinking in rats. Psychopharmacology (Berl) 132:350-360. 